\title{
Landfill Gas Cleanup for Carbonate Fuel Cell Power Generation CRADA MC95-031, Final Report
}

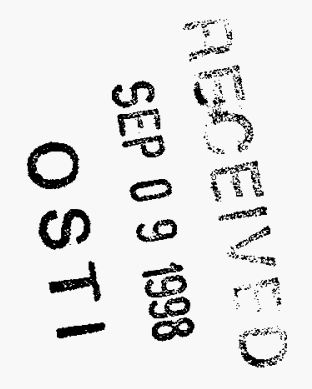

February 1998

U.S. Department of Energy

Federal Energy Technology Center

P.O. Box 880

3610 Collins Ferry Road

Morgantown, WV 26507-0880

and

Electric Power Research Institute

3412 Hillview Drive

Palo Alto, CA 94304-1395

DISTRBUTTON OF THIS DOCUMENT IS UNLINTED 


\section{Disclaimer}

This report was prepared as an account of work sponsored by an agency of the United States Government. Neither the United States Government nor any agency thereof, nor any of their employees, makes any warranty, express or implied, or assumes any legal liability or responsibility for the accuracy, completeness, or usefulness of any information, apparatus, product, or process disclosed, or represents that its use would not infringe privately owned rights. Reference herein to any specific commercial product, process, or service by trade name, trademark, manufacturer, or otherwise does not necessarily constitute or imply its endorsement, recommendation, or favoring by the United States Government or any agency thereof. The views and opinions of authors expressed herein do not necessarily state or reflect those of the United States Government or any agency thereof.

This report has been reproduced directly from the best available copy.

FETC's Internet Address: www.fetc.doe.gov 


\section{DISCLAIMER}

Portions of this document may be illegible in electronic image products. Images are produced from the best available original document. 


\title{
Landfill Gas Cleanup for Carbonate Fuel Cell Power Generation
}

\author{
Final Report
}

February 1998

\section{Prepared By:}

Energy Research Corporation

3 Great Pasture Road

Danbury, CT 06813

George Steinfeld and Robert Sanderson

\section{Prepared For:}

National Renewable Energy Laboratory 1617 Cole Boulevard

Golden, CO 80401-3393

Philip B. Shepherd

\section{U.S. Department of Energy}

Federal Energy Technology Center

P.O. Box 880

3610 Collins Ferry Road

Morgantown, WV 26507-0880

Tom J. George and William C. Smith

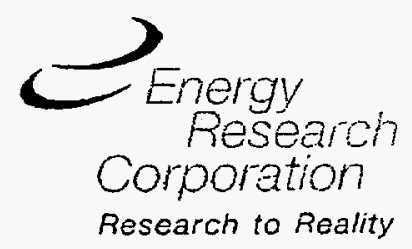




\section{ACKNOWLEDGEMENTS}

This effort was supported by the U.S. Department of Energy Federal Energy Technology Center (DOE/FETC), the National Renewable Energy Laboratory, and the Electric Power Research Institute (EPRI). Additional supporters include the National Rural Electric Cooperative Association (NRECA), Empire State Electric Energy Research Corporation (ESEERCO), Tennessee Valley Authority (TVA), and Northern States Power Company.

The DOE/FETC COTR's are Mr. Tom George and Mr. Cary Smith. The NREL COTR is Mr. Philip Shepherd. The EPRI project manager is Mr. Doug Herman. The ERC Program Manager (MCFC Product Design Improvement) is Dr. Mohammad Farooque. The Task Manager (Landfill Gas Proof of Concept Test) is Mr. George Steinfeld. The technical effort was managed by Doug Herman (EPRI) with support from George Steinfeld (Energy Research Corporation) and consultant David Thimsen. Subcontractors Kaltec of Minnesota and Interpoll Laboratories Inc. conducted field operations and gas/ solids analytical activities, respectively.

Testing and analysis conducted by Energy Research Corporation were carried out by Robert Sanderson (system analysis, design and cost estimating), Larry Paetsch and Jennifer Hunt (fuel cell stack testing), Geoff Muggleton (single cell testing), Usha Kaul (post test analysis of single cells), and Chao-Yi Yuh and Richard Johnsen (single cell data analysis). 
Page No.

EXECUTIVE SUMMARY 1

$\begin{array}{lll}1.0 & \text { INTRODUCTION } & 5\end{array}$

2.0 LFG COMPOSITION FOR BULK AND TRACE COMPOUNDS 7

3.0 EVALUATION OF VARIOUS METHODS TO CLEAN LANDFILL GAS 10

3.1 REMOVAL OF ORGANIC COMPOUNDS 11

3.1.1 Removal of Organic Impurities by Adsorption 11

3.1.2 Removal of Organic Impurities by Absorption 11

$\begin{array}{lll}\text { 4.0 DESIGN OF LFG CLEANUP PROCESS } & 12\end{array}$

4.1 ALLOWABLE CONTAMINANT LEVELS FOR CARBONATE FUEL CELLS 12

$\begin{array}{lll}4.2 & \text { REQUIRED PERFORMANCE } & 13\end{array}$

4.3 LANDFILL GAS CLEANUP PROCESS DESIGN 13

4.4 PROCESS UNCERTAINTIES REQUIRING FIELD TESTING 15

4.4.1 Bulk Sulfur Sorbent Loading Levels $\quad 15$

4.4.2 Bulk Chlorinated Hydrocarbon Capture 16

$\begin{array}{ll}4.4 .3 \text { Organic Chlorine Hydrogenation } & 16\end{array}$

5.0 FIELD TEST OF PILOT-SCALE GAS CLEANUP PROCESS 17

$\begin{array}{lll}5.1 & \text { DESCRIPTION OF LANDFILL SITE } & \cdot 17\end{array}$

$\begin{array}{lll}5.2 & \text { TEST FACILITY AND PROCEDURES } & 18\end{array}$

5.2.1 Process Equipment 18

$\begin{array}{ll}\text { 5.2.2 Data Collection Equipment and Procedures } & 19\end{array}$

5.31000 HOUR LFG CLEANUP TEST AT ANOKA 20

5.3.1 Operational History $\quad 20$

5.3.2 Bulk Gas Chromatograph Operation 23

5.3.3 Trace Gas Contaminant Sampling 24 
TABLE OF CONTENTS

Page No.

6.0 FUEL CELL TESTING ON SIMULATED LANDFILL GAS 31

6.1 SIMULATED LANDFILL GAS OPERATION 31

7.0 SINGLE CELL TESTING ON LANDFILL GAS CONTAMINANTS AND POST TEST ANALYSIS

8.0 DESIGN AND ECONOMIC ANALYSIS OF FULL SCALE GAS CLEANUP SYSTEM

8.1 TYPICAL LANDFILL GAS COLLECTION SYSTEM 41

8.2 PROTOTYPE GAS CLEANUP SYSTEM DESIGN GUIDE 41

8.2.1 Overall Design $\quad 41$

8.2.2 Bulk Sulfur Removal 44

8.2.3 Trace Sulfur Removal 45

8.2.4 Chlorinated Hydrocarbon Removal 45

8.3 COST ESTIMATES $\quad 46$

8.3.1 Gas Collection System Capital Costs 46

8.3.2 Gas Collection System Operating Costs 49

8.3.3 Gas Collection System Cost Summary $\quad 49$

8.3.4 Gas Cleaning System Capital Costs $\quad 49$

8.3.5 Gas Cleaning System Operating Costs 50

8.3.6 Gas Collection/Cleaning System Overall Cost Summary And Cost Sensitivies 50

9.0 CONCLUSIONS

$\begin{array}{ll}\text { APPENDIX } & 56\end{array}$ 


\section{LIST OF FIGURES}

Page No.

E-1 Landfill Gas Cleanup Process Flow Schematic 2

E-2 Landfill Gas Cleanup Cost Sensitivity 3

2-1 Anoka Minnesota Landfill Gas Bulk Composition 8

4-1 Prototype Landfill Gas Cleaning Process Block Flow Diagram 15

5-1 The Anoka County Regional Landfill 17

$\begin{array}{lll}5-2 & \text { LFG Cleanup Testing Facility } & 18\end{array}$

5-3 LFG Gas Treatment Process as Tested at Anoka 19

5-4 Gas Treatment Process Testing Landfill Gas Flow 22

5-5 Raw Landfill Gas Bulk Composition $\quad 25$

5-6 Polished Landfill Gas Bulk Composition 25

5-7 Hydrogen Sulfide Concentrations 26



$\begin{array}{lll}5-9 & \text { Dimethyl Sulfide Concentrations } & 27\end{array}$

5-10 Chlorinated Hydrocarbon Concentration Data Summary . 29

6-1 32kW Carbonate Fuel Cell Stack Tested on Simulated LFG 31

6-2 Simulated Fuel Cell Performance on Anoka Landfill Gas 32

6-3 Operating History of 32kW Stack on Simulated LFG 34

6-4 32kW Stack Test on LFG Compared to Natural Gas 35

7-1 Carbonate Electrolyte Loss Caused by Chloride in the Feed Streams 


\section{LIST OF FIGURES}

Page No.

7-2 Subscale Single Cell Test Facility

7-3 Single Cell Test on Simulated LFG with $300 \mathrm{ppb}$ Chloride Contaminant

7-4 Single Cell Test on Simulated LFG with $300 \mathrm{ppb} \mathrm{Cl}$ and S Contaminant

8-1 3 MW LFG Cleanup System Preliminary Equipment Layout

8-2 Hydrogen Sulfide Equilibrium Over Zinc Oxide

8-3 Hydrogen Chloride Equilibrium Over Potassium Carbonate

8-4 Landfill Gas Cleanup Cost Sensitivity 


\section{LIST OF TABLES}

Page No,

2-1 Typical Composition of Landfill Gas

2-2 Landfill Gas Contaminants at tWO Sites

3-1 Gas Cleanup Methods for Organic and Sulfur Compounds

4-1 Carbonate Fuel Cell Contaminant Tolerances

4-2 Required Landfill Gas Contaminant Cleanup Levels

5-1 Sampling and Analytical Procedures

5-2 Landfill Gas Treatment Testing, Operational Phases

6-1 Simulated Landfill Gas Compositions

8-1 Landfill Gas Composition Before and After Cleanup

8-2 Design Basis for Bulk Hydrogen Sulfide Removal Using SulfaTreat

8-3 Landfill Gas Cleanup System Sorbent and Catalyst Costs

8-4 Landfill Gas Collection/Cleanup Cost Summary 


\section{EXECUTIVE SUMMARY}

Landfill gas represents a significant fuel resource both in the United States and world wide. The emissions of landfill gas from existing landfills has become an environmental liability contributing to global warming and causing odor problems. Landfill gas has been used to fuel reciprocating engines and gas turbines, and may also be used to fuel carbonate fuel cells. Carbonate fuel cells have high conversion efficiencies and use the carbon dioxide present in landfill gas as an oxidant. There are, however, a number of trace contaminants in landfill gas that contain chlorine and sulfur which are deleterious to fuel cell operation. Long-term economical operation of fuel cells fueled with landfill gas will, therefore, require cleanup of the gas to remove these contaminants. The overall objective of the work reported here was to evaluate the extent to which conventional contaminant removal processes could be combined to economically reduce contaminant levels to the specifications for carbonate fuel cells. This effort was supported by the Department of Energy (DOE), National Renewable Energy Laboratory (NREL), Electric Power Research Institute (EPRI) with additional supporters as listed in the Introduction. The technical effort was conducted by EPRI, consultant David Thimsen, Kaltec of Minnesota, Energy Research Corporation (ERC) and Interpoll Laboratories.

The Electric Power Research Institute (EPRI) made available two test skids originally used to test an ERC $30 \mathrm{~kW}$ carbonate fuel cell at the Destec Coal Gasification Plan in Plaquemine, LA. EPRI's carbonate fuel cell pilot plant was installed at the Anoka County Regional Landfill in Ramsey, Minnesota. Additional gas cleaning equipment was installed to evaluate a potentially inexpensive, multi-stage gas cleaning process to remove sulfur and chlorine in the gas to levels acceptable for long-term, economical carbonate fuel cell operation. The pilot plant cleaned approximately $970,000 \operatorname{scf}\left(27,500 \mathrm{Nm}^{3}\right)$ of gas over 1000 hours of operation. The testing showed that the process could achieve the following polished gas concentrations:

- Less than 80 ppbv hydrogen sulfide

- $\quad$ Less than 1 ppmv (the detection limit) organic sulfur

- Less than 300 ppbv hydrogen chloride

- Less than 20-80 ppbv of any individual chlorinated hydrocarbon

- $\quad 1.5 \mathrm{ppm}$ sulfur dioxide

These were the detection limits of the analytical procedures employed. It is probable that the actual concentrations are below these analytical limits.

Figure E-1 shows the gas treatment system designed based on testing at the Anoka site. It consists of landfill gas compression followed by a bulk gas cleaning stage in which hydrogen sulfide concentration is reduced from $55 \mathrm{ppmv}$ to approximately $1 \mathrm{ppmv}$ by reaction with SulfaTreat, a proprietary iron oxide sorbent. Following the bulk gas cleaning stage, hydrogen is added to the gas just before trace sulfur and chloride removal. The gas polishing stage consists of conversion of organic sulfur to hydrogen sulfide and organic chlorine to hydrogen chloride by reaction with the hydrogen over a commercial 
hydrodesulfurization catalyst. The hydrogen chloride is removed from the gas by reaction with potassium carbonate, and the hydrogen sulfide is removed from the gas by reaction with zinc oxide.

The LFG cleanup process stands alone and can be applied to any landfill gas utilization project. It is capable of removing a wide variety of contaminants, including hydrogen sulfide, organic sulfur, chlorinated hydrocarbons, hydrogen chloride and oxygen. The process may also be tailored to various landfill gas utilization processes including fuel cells, combustion engines, boilers, pipeline quality upgrading, methanol production, etc.

The full-scale landfill gas cleanup system (sized to deliver sufficient gas to power a 2.8 MWe fuel cell) is designed to clean landfill gas to carbonate fuel cell inlet requirements for approximately \$1.0/MMBTU (using the Anoka operational data as a design basis). The utility power cost to operate the landfill gas compressor has the largest impact on the cleanup cost. As power cost is increased from the baseline $\$ 0.04 / \mathrm{kWh}$ to $\$ 0.12 / \mathrm{kWh}$, the baseline cleanup cost increases 33\% to \$1.34/MMBtu.

Sensitivity analysis indicates that as the level of contaminants in the landfill gas varies, there is a small impact on cost of cleanup as well. For a landfill which has three times the levels of all three contaminants, the landfill cleanup cost increases by about $23 \%$ to approximately $\$ 1.24 / \mathrm{MMBtu}$.

Figure E-2 shows the sensitivity of the levelized gas cost to the critical operational parameters.

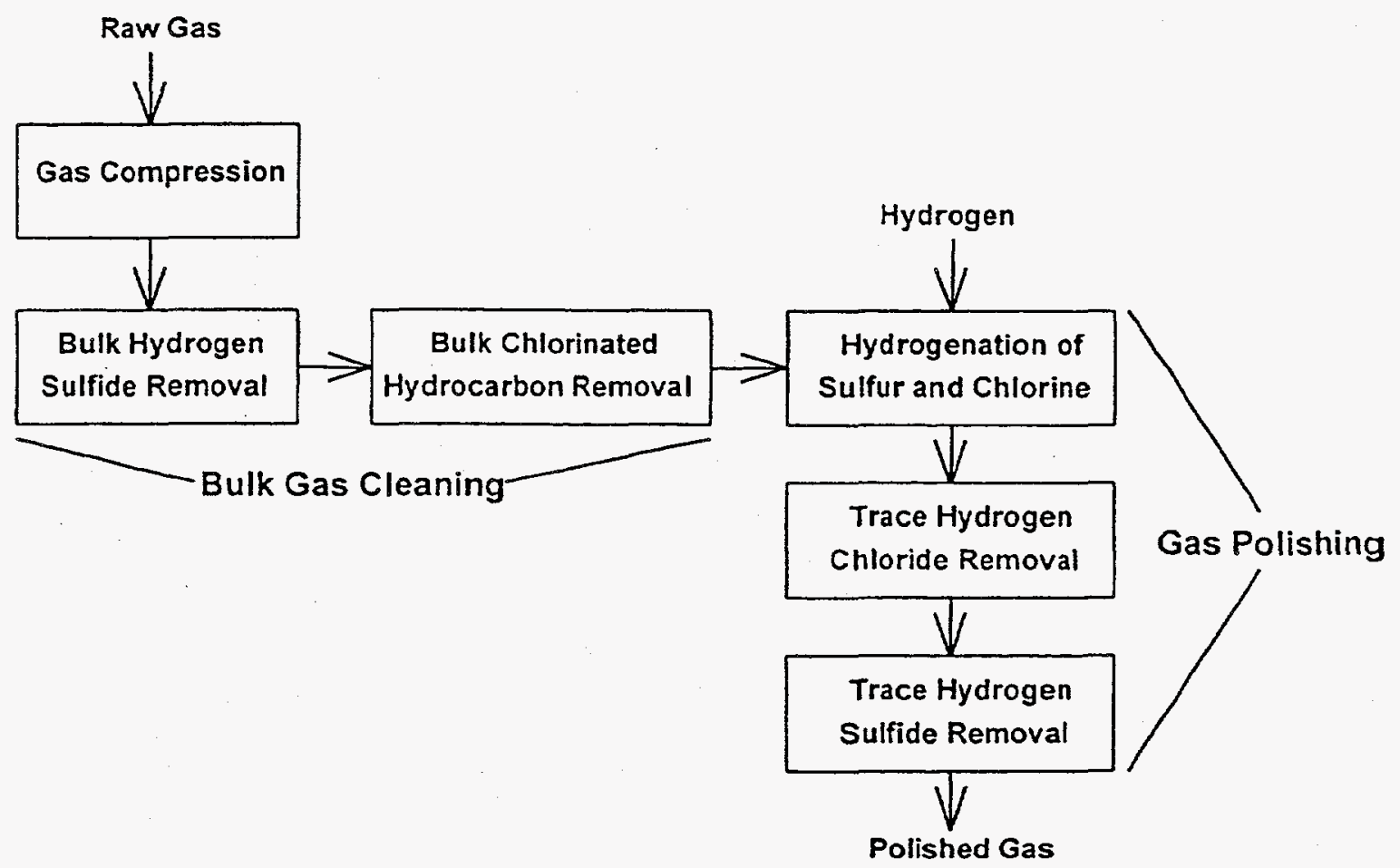

Figure E-1 LANDFILL GAS CLEANUP PROCESS FLOW SCHEMATIC:

This cleanup system was designed for a $2 \mathrm{MW}$ fuel cell power plant based on testing at Anoka. 


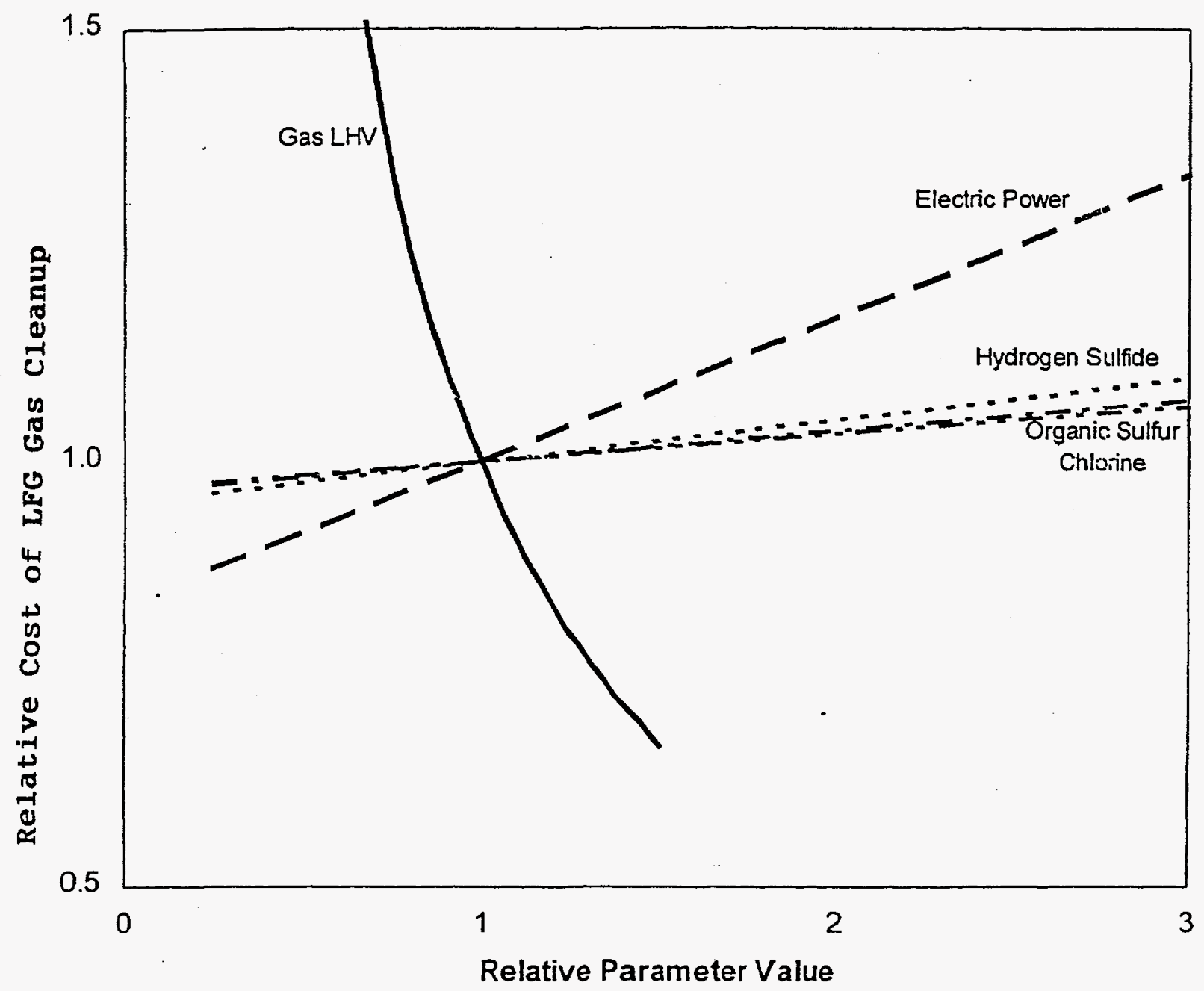

Figure E-2 LANDFILL GAS CLEANUP COST SENSITIVITY:

LFG Compression cost has the largest impact on LFG cleanup cost. Reference point is the Anoka landfill gas.

\section{BASELINE CONDITIONS:}

Gas LHV

Electric Power

Hydrogen Sulfide Concentration

Organic Sulfur Concentration

Chlorine Concentration

Cleanup Cost
$441 \mathrm{Btu} / \mathrm{scf}$

$\$ 0.04 / \mathrm{kWh}$

$40 \mathrm{ppmv}$

7 ppmv

9 ppmv

$\$ 1.01 / \mathrm{MMBtu}$ 
Single cell testing at ERC to assess the impact of higher tolerance levels for sulfur and chlorine contaminants in LFG were conducted at the $300 \mathrm{ppb}$ contaminant level. Based on two tests conducted, the presence of $300 \mathrm{ppb}$ chlorides did not result in severe decay rates compared to other standard cells tested. The $300 \mathrm{ppb}$ sulfur did result in noticeable contamination of internal reforming catalyst. The limited data of these two tests does not preclude a future increase in tolerance for chloride contaminants, however, additional long-term data is warranted to support this conclusion. Increasing the tolerance level for sulfur to $300 \mathrm{ppbv}$ is not considered desirable due to the impact on internal reforming catalyst.

The LFG clean-up system achieved a high degree of gas clean-up approaching the desired level of $100 \mathrm{ppb}$ total chlorides and $100 \mathrm{ppb}$ total sulfur. Additional effort is required to obtain gas analysis with lower detection limits to establish the levels desired, and to address the removal of sulfur dioxide.

A demonstration test is recommended to address the remaining technical issues of gas analysis detection limits and reduction of sulfur dioxide levels. Following demonstration of the cleanup system, a fuel cell LFG demonstration should be conducted. 


\subsection{INTRODUCTION}

Substantial amounts of methane are biologically generated in solid waste landfills. This methane is diluted with an approximately equal amount of a mixture of carbon dioxide, nitrogen, and trace compounds. Many of the trace compounds have been classified as pollutants when released to the atmosphere.

The U.S. Environmental Protection Agency (EPA)has ruled that large solid waste landfills must install landfill gas collection systems that preclude release of the raw landfill gas (and accompanying pollutants) to the atmosphere ${ }^{1}$. It is generally acceptable to burn the gas, oxidizing the pollutants to less harmful gaseous compounds. This is typically accomplished by incinerating the gas or burning it in combustion engines to generate power. The cleanup system developed in this project goes a step beyond EPA requirements in that contaminants are captured on solid sorbents rather than being released in oxidized form as gases to the environment.

The methane in landfill gas can be used to fuel carbonate fuel cells. There are, however, a number of trace contaminants containing chlorine or sulfur which are deleterious to carbonate fuel cell operation. Long-term economical operation of carbonate fuel cells fueled with landfill gas will require cleanup of the gas to remove these contaminants. EPRI estimates, conservatively, that landfill gas resources throughout the United States could support $6000 \mathrm{MW}$ of power generation if utilized in $2 \mathrm{MW}$-size carbonate fuel cell plants ${ }^{2}$.

In order to evaluate the requirements and technical options for using landfill gas in carbonate fuel cells, a cooperative research program was established including the Electric Power Research Institute, U.S. Department of Energy, National Rural Electric Cooperative Association, National Renewable Energy Laboratory, United Power Association, Empire State Electric Energy Research Corporation (ESEERCO), Tennessee Valley Authority (TVA), and Northern States Power Company. The original objective of the project was to demonstrate the feasibility of generating electricity from landfill gas using a carbonate fuel cell. An EPRI-owned fuel cell pilot plant, previously used for the world's first demonstration of a carbonate fuel cell operating on gasified coal fuel ${ }^{3}$, was transported to the Anoka County Regional Landfill in Ramsey, Minnesota.

As engineering proceeded for the carbonate fuel cell installation, it became

\footnotetext{
${ }^{1}$ Environment Reporter, March 8, 1996. "Clean Air Rule Requires Landfill Owners to Install Intricate Gas Collection Systems."
} June 1994

2EPRI TB-104053. "Demonstration of Landfill Gas Utilization by Carbonate Fuel Cells,"

${ }^{3}$ EPRI TR-103285. "Demonstration of a Carbonate Fuel Cell on a Coal-Derived Gas." December 1993 
apparent that there was no commercially available gas cleanup system that would meet the very stringent inlet gas quality specifications of carbonate fuel cells. Landfill gas flow rates and the contaminant levels in landfill gas are relatively low compared to conventional fossil fuel cleanup processes (i.e. gas sweetening plants). Thus, many commercial gas cleaning processes (developed for conventional fossil fuels) are unsuitable because they are either uneconomical in small sizes (i.e., at low gas flow rates) or were designed for much larger inlet contaminant concentrations and could not achieve the low levels of clean-up.

While there are commercial landfill gas cleaning installations in service (particularly for sulfur contaminants), these are designed to reduce contaminants to the relatively higher levels tolerated by other power generation technologies. In most cases, no gas cleanup is employed and the problems (primarily corrosion) caused by the contaminants are dealt with by increased maintenance or by changing bearing materials and lubricant chemistry.

The focus of the project shifted to developing an economical landfill gas cleanup process suitable to meet the carbonate fuel cell inlet specifications but which might be applicable to a wide range of landfill gas utilization technologies. The overall objective of the work reported here was to evaluate the extent to which conventional contaminant removal processes could be combined to economically reduce contaminant levels to the specifications for carbonate fuel cells. 


\subsection{LFG COMPOSITION FOR BULK AND TRACE COMPOUNDS}

Landfill gas (LFG) consists primarily of methane and carbon dioxide, as shown in Table 2-1. The higher heating value of LFG is $400-550 \mathrm{Btu} / \mathrm{scf}$. LFG also contains a significant amount of water vapor and traces of organic compounds. The organic compounds result from the man-made solvents, propellants and similar materials deposited in the landfill. LFG can also have nitrogen, and sometimes small amounts of oxygen related to air entrainment. LFG also contains a significant amount of particulate material related to the gas collection process. Table 2-1 shows the typical composition and principal contaminants listed by the EPA ${ }^{1}$ and levels measured at the Anoka Landfill during tests conducted in 1994.

Table 2-1 TYPICAL COMPOSITION OF LANDFILL GAS

LFG contains significant levels of methane, as well as trace contaminants.

\begin{tabular}{|l|c|c|}
\hline \multicolumn{1}{|c|}{ COMPONENT } & $\begin{array}{c}\text { TYPICAL LANDFILL } \\
\text { LEVEL }\end{array}$ & $\begin{array}{c}\text { ANOKA LANDFILL } \\
\text { LEVEL }\end{array}$ \\
\hline Methane, \% & $40-55$ & 52.2 \\
\hline Carbon Dioxide, \% & $35-50$ & 38.1 \\
\hline Water Vapor, \% & $1-10$ & Saturated \\
\hline Nitrogen, \% & $0-20$ & 9.1 \\
\hline Oxygen, \% & & $0.5-1.0$ \\
\hline Condensible Hydrocarbons, (ROGs) ppmv & $250-3000$, as hexane & 136 \\
\hline Organic Chlorine Compounds, micrograms/liter & $30-300$ & $38(8.4 \mathrm{ppmv})$ \\
\hline Hydrogen Sulfide, ppm & to 200 & 53 \\
\hline
\end{tabular}

The variation in bulk composition measured at the Anoka site over 1002 hours of testing is shown in Figure 2-1. The concentration of oxygen is tracked by the concentration of nitrogen. Variations in $\mathrm{N}_{2}$ and $\mathrm{O}_{2}$ appeared to correlate with variations in barometric pressure indicating infiltration of air.

The contaminants in LFG are site specific, as shown in Table 2-2. The contaminants are listed for LFG from the Penrose Landfill in Los Angeles (Sun Valley), California, and the Anoka Minnesota Landfill. As shown in Table 2-2, the total hydrocarbons varied from 31 to $1634 \mathrm{ppm}$ and the total halogenated hydrocarbons varied from 8 to 101 between the two sites. Trichloroethylene, which at one time was a common solvent for cleaning metals during manufacturing, was $70 \mathrm{ppm}$ at the Penrose, California site, but zero at the Anoka site. The total sulfur compounds varied from 60 to $121 \mathrm{ppm}$ between the sites.

${ }^{1}$ EPA-600/R-92-116, Landfill Gas Energy Utilization Technology Options and Case Studies by Emcon Associated, June 1992. 


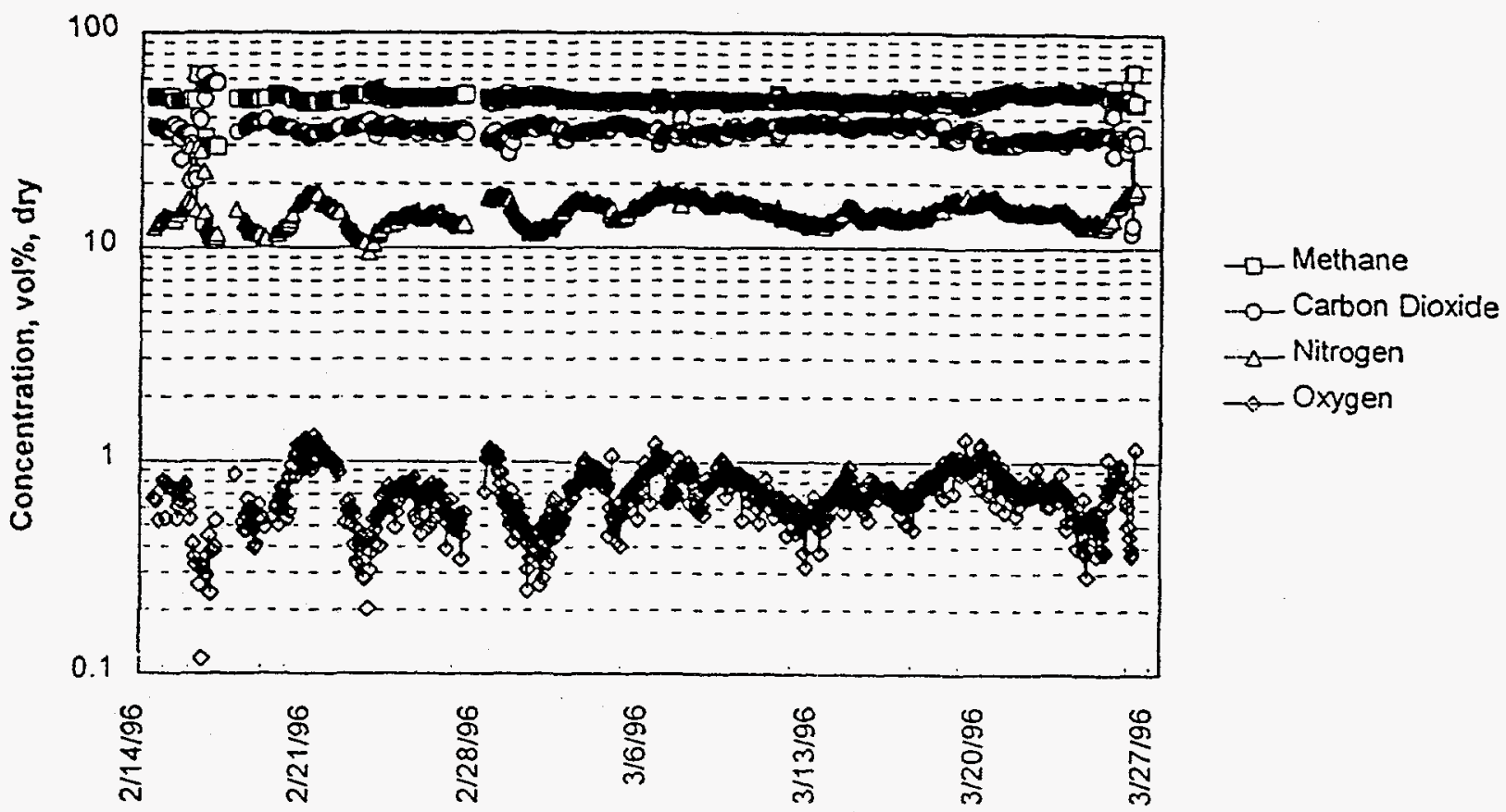

Figure 2-1 ANOKA MINNESOTA LANDFILL GAS BULK COMPOSITION:

Methane and $\mathrm{CO}_{2}$ concentrations are stable while $\mathrm{N}_{2}$ and $\mathrm{O}_{2}$ vary due to air infiltration. 
Table 2-2 LANDFILL GAS CONTAMINANTS AT TWO SITES:

LFG contaminant levels vary from site to site.

\begin{tabular}{|c|c|c|}
\hline CONTAMINANT & $\begin{array}{l}\text { PENROSE, CA } \\
\text { Level, ppmv }\end{array}$ & $\begin{array}{l}\text { ANOKA, MN } \\
\text { Level, ppmv }\end{array}$ \\
\hline $\begin{array}{l}\text { HYDROCARBONS, TOTAL } \\
\text { Butane, } \mathrm{C}_{4} \mathrm{H}_{10} \\
\text { 2 Butanone, } \mathrm{C}_{8} \mathrm{H}_{8} \mathrm{O} \text {, ethyl methyl ketone } \\
\text { Propane, } \mathrm{C}_{3} \mathrm{H}_{8} \\
\text { Isobutane, } \mathrm{C}_{4} \mathrm{H}_{10} \\
\text { Isopentane, } \mathrm{C}_{5} \mathrm{H}_{12} \\
\text { n-Pentane, } \mathrm{C}_{5} \mathrm{H}_{12} \\
\text { Hexane, } \mathrm{C}_{8} \mathrm{H}_{8} \mathrm{O} \\
\text { Octane, } \mathrm{C}_{8} \mathrm{H}_{14} \mathrm{O}_{4}\end{array}$ & $\begin{array}{c}1634 \\
\\
\\
95 \\
963 \\
198 \\
297 \\
81\end{array}$ & $\begin{array}{c}31 \\
7 \\
16 \\
8\end{array}$ \\
\hline $\begin{array}{l}\text { AROMATICS, TOTAL } \\
\text { Benzene, } \mathrm{C}_{6} \mathrm{H}_{6} \\
\text { Chlorobenzene, } \mathrm{C}_{6} \mathrm{H}_{5} \mathrm{Cl} \\
\text { Ethene, } \mathrm{C}_{2} \mathrm{H}_{4} \\
\text { Xylene, } \mathrm{C}_{8} \mathrm{H}_{10} \\
\text { Ethylbenzene, } \\
\text { Styrene, } \mathrm{C}_{8} \mathrm{H}_{8} \\
\text { n-Heptane, } \mathrm{C}_{7} \mathrm{H}_{16} \\
\text { Toluene, } \mathrm{C}_{7} \mathrm{H}_{8}\end{array}$ & $\begin{array}{c}72.5 \\
2 \\
1 \\
\\
22 \\
13 \\
0.5 \\
\\
35\end{array}$ & $\begin{array}{c}173 \\
1.1 \\
\\
37 \\
62 \\
37 \\
3 \\
2 \\
31\end{array}$ \\
\hline $\begin{array}{l}\text { HALOGENATED } \mathrm{HYDROCARBONS} \\
\text { TOTAL } \\
\text { Dichloroethene, } \mathrm{C}_{2} \mathrm{H}_{2} \mathrm{Cl}_{2} \mathrm{O} \\
\text { DichloroBenzene, } \mathrm{C}_{6} \mathrm{H}_{4} \mathrm{Cl}_{2} \\
\text { Dichlorodifluromethane } \text { (Freon 12) } \mathrm{CCl}_{2} \mathrm{~F}_{2} \\
\text { Dichloroethene, cis, } \mathrm{C}_{2} \mathrm{H}_{2} \mathrm{Cl}_{2} \text { (Vinylidene) } \\
\text { Dichloromethane, } \mathrm{CH}_{2} \mathrm{Cl}_{2} \\
\text { Methylene Chloride, } \mathrm{C}_{2} \mathrm{H}_{3} \mathrm{ClO}_{2} \\
\text { Trichlorofluroethane, } \mathrm{CCl}_{3} \mathrm{~F} \\
\text { Trichloroethylene, } \mathrm{C}_{2} \mathrm{HCl}_{3} \\
\text { Trichlorofluromethane }(\mathrm{Freon} 11), \mathrm{CCl}_{3} \mathrm{~F} \\
\text { Trichloroethene, } \mathrm{C}_{2} \mathrm{HCl}_{3} \\
\text { Tetrachloroethene, } \mathrm{C}_{2} \mathrm{Cl}_{4} \\
\text { Tetrachloroethylene, } \mathrm{C}_{2} \mathrm{Cl}_{4} \\
\text { Vinyl Chloride, } \mathrm{C}_{2} \mathrm{H}_{3} \mathrm{Cl}\end{array}$ & $\begin{array}{c}101 \\
3 \\
5\end{array}$ & $\begin{array}{c}8.36 \\
1.5 \\
1 \\
3 \\
\\
0.35\end{array}$ \\
\hline $\begin{array}{l}\text { SULFUR COMPOUNDS, TOTAL } \\
\text { Hydrogen Sulfide, } \mathrm{H}_{2} \mathrm{~S} \\
\text { Methyl Mercaptan, } \mathrm{CH}_{3} \mathrm{SH} \\
\text { Ethyl Mercaptan, } \mathrm{C}_{2} \mathrm{H}_{5} \mathrm{SH} \\
\text { Dimethyl Sulfide, } \mathrm{C}_{2} \mathrm{H}_{6} \mathrm{~S} \\
\text { Dimethyl Disulfide, } \mathrm{C}_{2} \mathrm{H}_{6} \mathrm{~S}_{2} \\
\end{array}$ & $\begin{array}{c}121.02 \\
103 \\
5 \\
5 \\
8 \\
0.02 \\
\end{array}$ & $\begin{array}{l}60 \\
53 \\
2.1 \\
4.9\end{array}$ \\
\hline
\end{tabular}




\subsection{EVALUATION OF VARIOUS METHODS TO CLEAN LANDFILL GAS}

Landfill gas typically consists of approximately $49 \%$ methane, $39.5 \%$ carbon dioxide, $1.5 \%$ water vapor, $9 \%$ Nitrogen, and $0.5 \%$ oxygen. In addition, it also contains undesirable trace compounds such as sulfur compounds and chlorinated hydrocarbons, as discussed in Section 2.0. These trace compounds, if not removed, can lead to unacceptable products of combustion, pollution of the environment, odors, and corrosion of gas treating process equipment. The potential for equipment corrosion is due to the formation of hydrochloric and sulfuric acid. When utilizing fuel cells to generate power using LFG, the sulfur compounds and chlorinated hydrocarbons present also pose a hazard to fuel cell operation due to the deleterious effect on catalysts used in the fuel cell power plant. These compounds must, therefore, be removed in a cleanup system prior to use of LFG.

The principal classes of trace compounds found in LFG are as follows:

1. Organic compounds, saturated and unsaturated, having a molecular weight greater than methane and essentially insoluble in water,

2. Organic alcohols and acid hydrocarbons, mostly soluble in water,

3. Aromatic hydrocarbons,

4. Halogenated hydrocarbons (primarily chlorinated hydrocarbons),

5. Sulfur compounds, such as hydrogen sulfide, carbonyl sulfide, carbon disulfide, and mercaptans, and

6. Inorganics, inerts, and other compounds not falling into any of the above categories.

Existing gas cleanup systems used in the Chemical Process Industries (CPI) that are applicable to LFG are summarized in Table 3-1 below.

Table 3-1 GAS CLEAN-UP METHODS FOR ORGANIC AND SULFUR COMPOUNDS: A combination of processes is required to cleanup LFG.

\begin{tabular}{|c|c|}
\hline ORGANIC COMPOUNDS & SULFUR COMPOUNDS \\
\hline $\begin{array}{l}\text { adsorption using carbon beds, PSArTSA } \\
\text { absorption using solvents such as } \\
\text { methanol, Selexol, liquid } \mathrm{CO}_{2} \\
\text { carbon (does not remove carbonyl } \\
\text { sulfide) } \\
\text { refrigeration to condense organic } \\
\text { compounds }\end{array}$ & $\begin{array}{l}\text { - } \quad \text { iron oxide such as Sulfatreat } \\
\text { - } \quad \text { acid gas removal (such as MEA } \\
\text { and DEA among others) }\end{array}$ \\
\hline
\end{tabular}




\subsection{REMOVAL OF ORGANIC COMPOUNDS}

As shown in Table 3-1, removal of organic compounds can be achieved by the following methods:

- adsorption onto a solid such as carbon or alumina, or PSA

- absorption by a liquid solvent or solvents

- refrigeration

\subsubsection{Removal of Organic Impurities by Adsorption}

Carbon beds are considered effective for removal of most volatile organic compounds found in LFG. The carbon beds are either replaced when saturated or regenerated. If regeneration is chosen, two beds can be used where one is absorbing and one is regenerating. The regeneration gas leaving the carbon bed contains the trace compounds removed from the landfill gas. This gas is then incinerated in a thermal oxidizer. Disposable carbon beds are only feasible in extremely small landfill recovery units, since the typical size landfill (larger than 1 MMSCFD) would saturate the carbon bed with organic compounds too quickly. However, disposable carbon beds may be economically applied for final removal of trace compounds after bulk removal has been achieved by some other means such as partial absorption in a solvent, or by partial condensation using refrigeration.

Organic chlorides and hydrogen chloride are commercially removed by using chloride guard sorbents which consist mainly of activated alumina. Variations on this include potassium carbonate and calcium oxide promoted formulations. These are typically used down stream of Hydrodesulfurization reactors and can operate at the same temperature, typically $750^{\circ} \mathrm{F}$. Activated alumina can be used at temperatures ranging from ambient to $750^{\circ} \mathrm{F}$ and has an absorption capacity of up to $19 \mathrm{Wt} \%$ Chloride. When saturated, the activated alumina is replaced with fresh material.

\subsubsection{Removal of Organic Impurities by Absorption}

Organic impurities can be removed by absorption into solvents such as methanol, liquid $\mathrm{CO}_{2}$, and Selexol. Methanol is a well-proven solvent in the oil and gas industry. It is used as the physical solvent in the Rectisol process licensed by Lurgi of Germany. It is also used in the Kryosol process licensed by Kryos Engineering Inc. of New York, and has been specifically designed for the treatment of LFG'

The Selexol solvent (Dimethylether of Polyethylene Glycol) has been used in the removal of volatile organic compounds. This process is licensed by the Norton Company of Akron, Ohio, through GSF Energy of Austin, Texas and is used at the Fresh Kills Landfill Gas Recovery Facility in Staten Island New York among other sites.

${ }^{1}$ PB88 217021, SCS Engineers Inc. and Lummus Crest, Inc.. (A.P. Keller), "Trace Constituents in Landfill Gas", Task Report on Inventory and Assessment of Cleaning Technologies, Prepared for Gas Research Institute, April 1988. 


\subsection{DESIGN OF LFG CLEANUP SYSTEM}

\subsection{ALLOWABLE CONTAMINANT LEVELS FOR CARBONATE FUEL CELLS}

Hydrocarbon fuels, by their very nature, contain trace species of various types in addition to the hydrocarbons desirable for industrial use and for power generation. Concentrations of these trace species are usually reduced to lower levels during processing of hydrocarbons for environmental and operational reasons. Landfill gas, which is derived from decomposition of various types of municipal organic wastes, also contains trace contaminants which are of concern both from an environmental point of view and from an operational point of view. The trace contaminants of primary concern in landfill gas are sulfur compounds and chlorinated hydrocarbons.

Based on research for coal gasification/fuel cell systems ${ }^{1}$, the maximum recommended contaminant levels are summarized in Table 4-1.

Table 4-1 CARBONATE FUEL CELL CONTAMINANT TOLERANCES:

Relevant contaminants are sulfur and chlorine compounds.

\begin{tabular}{|l|c|c|l|}
\hline CONTAMINANT & REACTION MECHANISM & TOLERANCE & CONCLUSIONS \\
\hline $\mathrm{H}_{2} \mathrm{~S}$ & $\mathrm{xH}_{2} \mathrm{~S}+\mathrm{Ni} \rightarrow \mathrm{NiS}_{\mathrm{x}}+\mathrm{xH}_{2}$ & $<100 \mathrm{ppbv} \mathrm{H}_{2} \mathrm{~S}$ & Recoverable Effect \\
\hline $\mathrm{HCl}$ & $2 \mathrm{HCl}+\mathrm{K}_{2} \mathrm{CO}_{3} \rightarrow 2 \mathrm{KCl}(\mathrm{v})+\mathrm{H}_{2} \mathrm{O}+\mathrm{CO}_{2}$ & $<100 \mathrm{ppbv} \mathrm{HCl}$ & Long-term Effects \\
\hline
\end{tabular}

The tolerance level established for each of the two primary contaminants of concern, sulfur and chlorides, is $100 \mathrm{ppbv}$ in the fuel gas. Sulfur in the fuel gas reacts with nickel catalyst in the fuel cell to form nickel sulfide. This results in reduced performance levels of reforming and electrochemical conversion of the fuel. The effect of chlorides is similar to that of sulfur in terms of effects on nickel catalyst. However, in addition, it can react with potassium carbonate electrolyte and form volatile potassium chloride. This causes a gradual depletion of electrolyte if allowed to continue on a large enough scale. At $100 \mathrm{ppbv}$ chlorides in the fuel gas, the rate of electrolyte depletion is acceptable.

Landfill gas can also contain oxygen due to leakage of air into the landfill. Oxygen in the landfill gas can oxidize nickel catalyst to nickel oxide. This will affect the pre-

Pigeaud A., H. Maru, G. Wilemski, J. Helble. Trace Element Emissions, Final Technical Report prepared by Energy Research Corporation for U.S. Department of Energy Morgantown Energy Technology. Contract No. DEAC21-92MC29261. February 1995. 
reforming catalyst and cause a gradual decline in catalytic activity. The tolerance level for oxygen in the fuel gas is estimated to be $0.2 \%$ vol.

\subsection{REQUIRED PERFORMANCE}

The required performance of the landfill gas cleanup system is summarized in Table 4-2. A reduction in gas phase sulfur in excess of $99.85 \%$ is required. A reduction in gas phase chlorine in excess of $99.39 \%$ is also required. Gas phase chlorine atom concentrations are greater than gas phase chlorinated hydrocarbon concentrations due to the fact that many of the chlorinated hydrocarbons contain more than one chlorine atom.

Table 4-2 REQUIRED LANDFILL GAS CONTAMINANT CLEANUP LEVELS:

LFG Contaminants must be removed almost completely.

\begin{tabular}{|l|c|c|c|}
\hline \multicolumn{1}{|c|}{ CONTAMINANT } & $\begin{array}{c}\text { RAW ANOKA LANDFILL } \\
\text { GAS CONCENTRATION } \\
\text { ppbV }\end{array}$ & $\begin{array}{c}\text { MAXIMUM CONCENTRA- } \\
\text { TION IN CLEANED GAS } \\
\text { ppbV }\end{array}$ & $\begin{array}{c}\text { MINIMUM } \\
\text { REMOVAL } \\
\text { REQUIRED }\end{array}$ \\
\hline Sulfur & 60,000 & $<100$ & $99.85 \%$ \\
\hline Chlorine (as chloride) & 16,500 & $<100$ & $99.39 \%$ \\
\hline
\end{tabular}

\subsection{LANDFILL GAS CLEANUP PROCESS DESIGN}

Hydrogen sulfide is a reactive gas and there are a number of commercial processes for removing hydrogen sulfide from process gas streams. The modest sulfur concentrations present in landfill gas at the Anoka site suggest that a throw-away sulfur sorbent would be most practical.

In order to achieve the very low sulfur concentrations required for carbonate fuel cell operation, reaction of hydrogen sulfide with zinc oxide to form non-volatile zinc sulfide is generally the process of choice. Zinc oxide is, however, fairly expensive and does not readily react with organic sulfur compounds (e.g. methyl mercaptan, dimethyl sulfide). Sulfur in the organic sulfur compounds is typically converted to hydrogen sulfide by reaction with hydrogen gas over a hydrodesulfurization catalyst before the gas comes in contact with the zinc oxide.

There are several comparatively inexpensive sulfur sorbents that are capable of reducing gas phase hydrogen sulfide to the $1000 \mathrm{ppbv}$ range. Thus, the overall process proposed here to achieve the $>99.85 \%$ removal is a three stage process:

1. Bulk removal of hydrogen sulfide by reaction with a relatively inexpensive sulfur sorbent. 
2. Conversion of organic sulfur to hydrogen sulfide by reaction with hydrogen over a hydrodesulfurization catalyst.

3. Removal of hydrogen sulfide traces by reaction with zinc oxide.

The chlorinated hydrocarbon contaminants in the landfill gas can be broadly divided into the low molecular weight contaminants (typified by chloroethene and chloromethane) and the high molecular weight compounds (typified by the dichlorobenzenes). Preliminary studies indicated that the low molecular weight compounds would be converted to hydrogen chloride at high yield under the process conditions that would be imposed during hydrodesulfurization.

There was more uncertainty as to whether the chlorine in the high molecular weight compounds would be likewise converted. The high molecular weight compounds can, however, be removed from the gas stream by adsorption onto activated carbon, a relatively inexpensive and regenerable material. There are a large number of non-chlorinated hydrocarbons in the landfill gas that are also adsorbed by activated carbon which may interfere with adsorption of the chlorinated compounds.

There are several commercially available sorbents that can remove the hydrogen chloride traces resulting from the hydrogenation stage. These include potassium carbonate and calcium oxide promoted chlorine guards.

The overall process proposed here to achieve the $>99.39 \%$ removal of gas phase chlorine is a three stage process:

1. Removal of some of the chlorinated hydrocarbons by adsorption onto activated carbon. (This stage was included, as a backup, to remove chlorinated aromatic compounds to cover the possibility that the chlorine in these compounds might not be fully converted to hydrogen chloride in stage 2 below.)

2. Conversion of organic chlorine to hydrogen chloride by reaction with hydrogen gas over a hydrodesulfurization catalyst

3. Removal of hydrogen chloride traces by reaction with potassium carbonate.

The overall process for the prototype gas cleanup process is shown in Figure 4-1. The raw landfill gas is compressed to approximately 3 atmospheres (absolute) to reduce process vessel and piping sizes (and costs) which are inversely proportional to pressure over moderate pressures.

SulfaTreat, a proprietary, commercial iron oxide formulation, is used to remove the bulk of the hydrogen sulfide. The sulfur capture reaction rates are limited by reaction kinetics. The supplier recommends operation at a temperature near $140^{\circ} \mathrm{F}\left(60^{\circ} \mathrm{C}\right)$ and saturated with water vapor. 


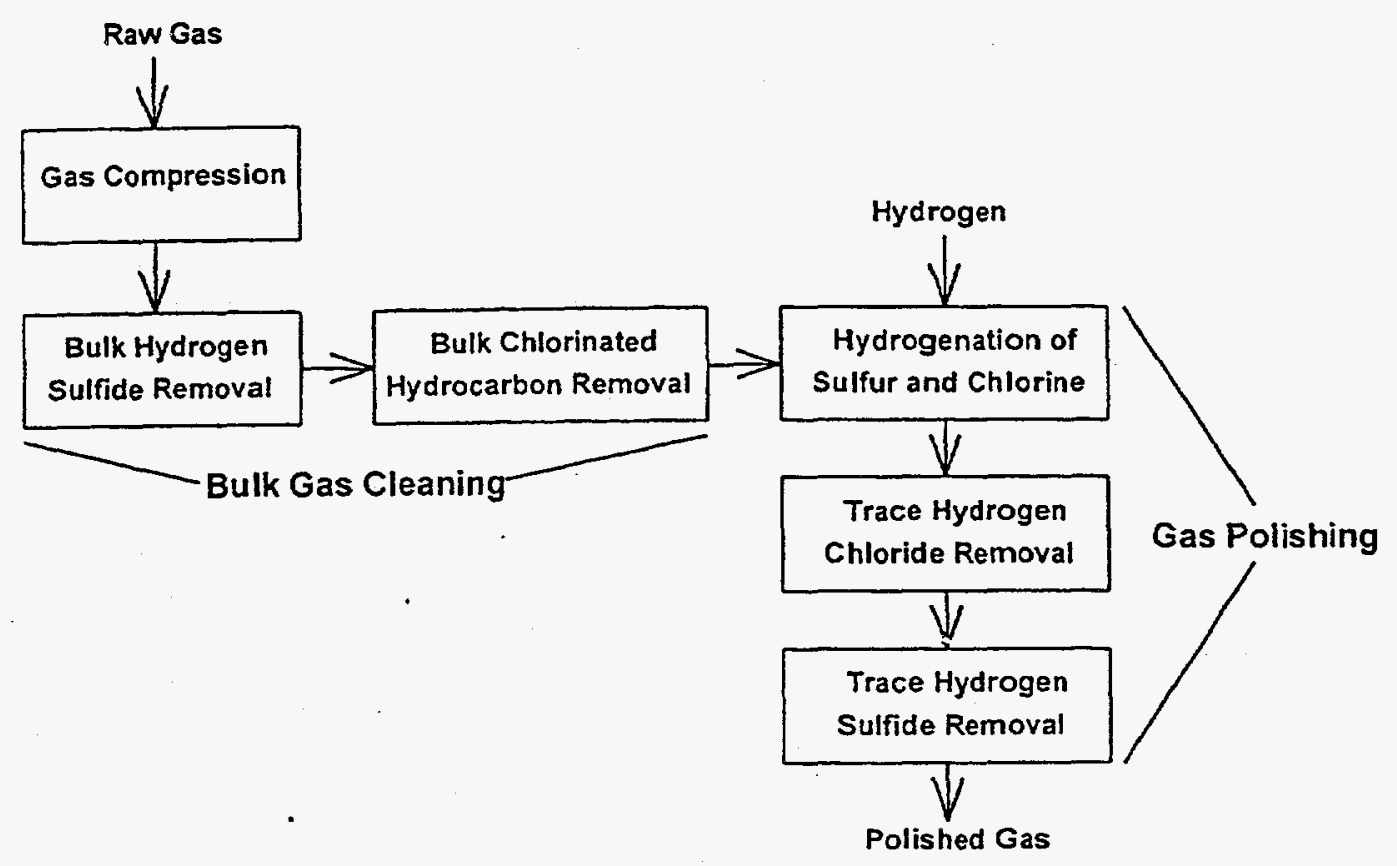

Figure 4-1 PROTOTYPE LANDFILL GAS CLEANING PROCESS BLOCK FLOW DIAGRAM:

Three stage LFG gas cleanup process designed for testing at Anoka.

Activated carbon adsorption is used to remove the bulk of the high molecular weight chlorinated hydrocarbons. In general, adsorption is improved as temperatures go down and water vapor content goes down. Adsorption is severely inhibited if liquid water is present. Thus, the operating temperature should be low, but well above the water dew point. This requirement is in conflict with the optimum conditions for the SulfaTreat. Landfill gas is typically saturated with water. The process design tested here was optimized for SulfaTreat conditions, and, thus, was not optimized for the activated carbon.

Residual gas phase sulfur is converted to hydrogen sulfide and residual gas phase chlorine is converted to hydrogen chloride at elevated temperature by reaction with hydrogen gas over the hydrogenation catalyst. Hydrogen chloride is removed by reaction with potassium carbonate at elevated temperature. Hydrogen sulfide is then removed by reaction with zinc oxide at elevated temperature.

\subsection{PROCESS UNCERTAINTIES REQUIRING FIELD TESTING}

The field test described in Section 5 was organized at the Anoka County Regional Landfill to confirm that the prototype gas cleanup process is capable of the deep cleaning required for carbonate fuel cell operation. The tests were designed to address several process uncertainties as identified below.

\subsubsection{Bulk Sulfur Sorbent Loading Levels}

Operating costs associated with bulk hydrogen sulfide removal are dependent on 
the amount of sulfur a given amount of sorbent can collect. As sulfide is captured by the sorbent, the hydrogen sulfide content of the gas leaving the sorbent beds rises. When the hydrogen sulfide content of the exit gas reaches the maximum allowable concentration, the sorbent must be replaced. The higher the sulfur content of the sorbent at replacement, the lower the operating costs.

\subsubsection{Bulk Chlorinated Hydrocarbon Capture}

The chlorinated hydrocarbons present in the raw landfill gas at the Anoka site were a very small fraction of the total non-methane hydrocarbons in the gas. Thus, there was some uncertainty as to how the presence of large amounts of adsorbed hydrocarbons would influence the adsorption of the relatively small concentrations of chlorinated hydrocarbons onto the activated carbon.

\subsubsection{Organic Chlorine Hydrogenation}

The ability of the hydrodesulfurization catalyst to convert organic chlorine to hydrogen chloride was not well documented. This is particularly true for the high molecular weight compounds such as the dichlorobenzenes. There was also some uncertainty in the extent to which chlorine in the landfill gas would react with the catalyst itself, potentially deactivating it. 


\subsection{FIELD TEST OF PILOT-SCALE GAS CLEANUP PROCESS}

\subsection{DESCRIPTION OF LANDFILL SITE}

The Anoka County Regional Landfill, shown in Figure 5-1, is located approximately 25 miles northwest of Minneapolis, Minnesota in the municipality of Ramsey, Minnesota. The landfill stopped accepting solid waste in 1994. In the fall of 1994 the landfill was covered with an impermeable layer on which 4 feet $(1.3 \mathrm{~m})$ of soil and topsoil were placed.

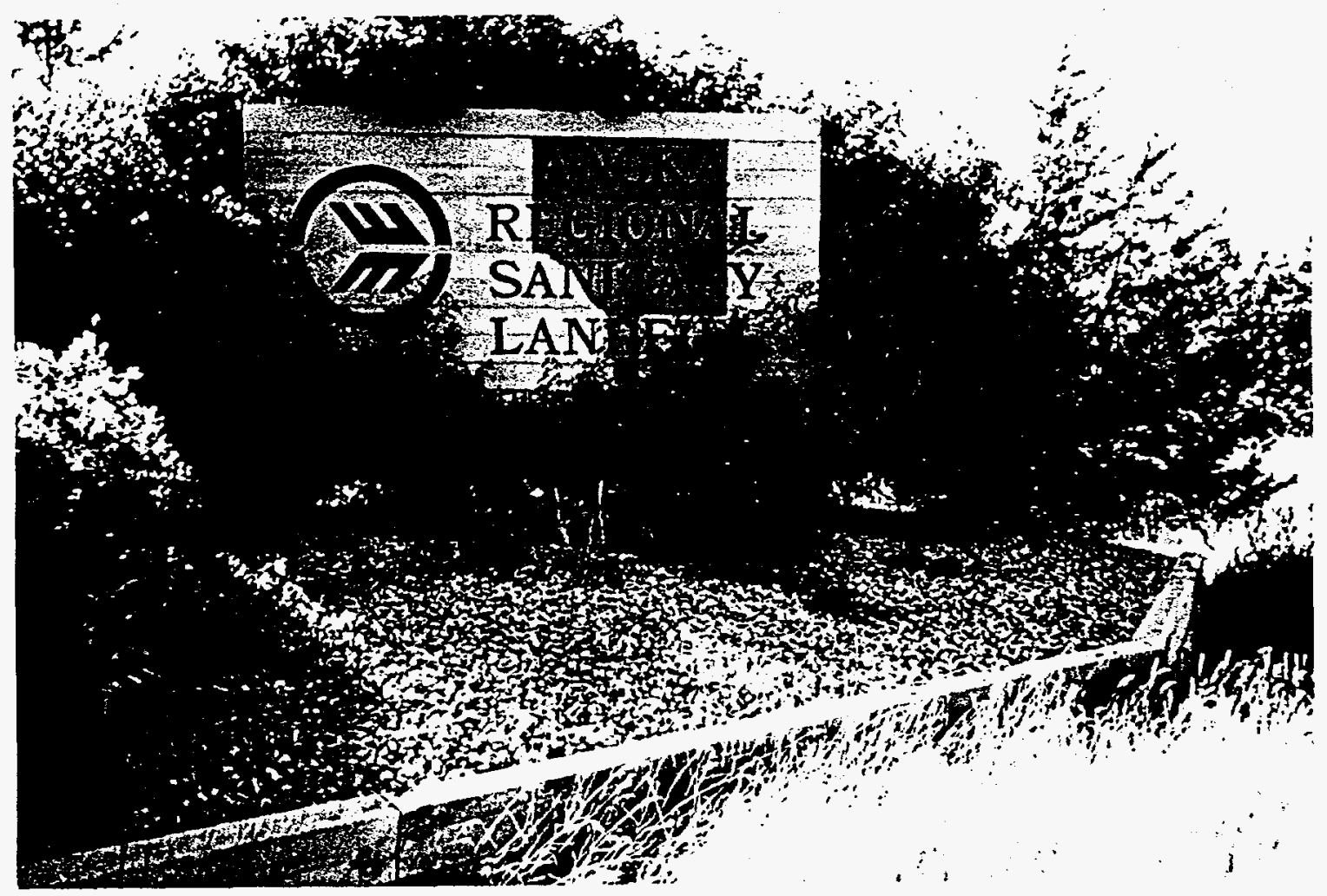

Figure 5-1 THE ANOKA COUNTY REGIONAL LANDFILL:

Located outside of Minneapolis, Minnesota.

The landfill gas collection system at the site consists of 47 gas collection wells which route the gas to an underground drop-out tank for moisture removal. The dewatered gas is then pressurized by centrifugal blowers ( 1 operating, 1 spare) from about -13 in.wg $(-3.2 \mathrm{kPa})$ to about $10 \mathrm{in} . \mathrm{wg}(2.5 \mathrm{kPa})$. The bulk of the gas is incinerated in a flare. A small amount is exported approximately half a mile to a local industry which uses it to generate $15 \mathrm{~kW}$ in a reciprocating engine.

A facility for testing the LFG Clean-up was constructed at the Anoka site by EPRI, as shown in Figure 5-2. 


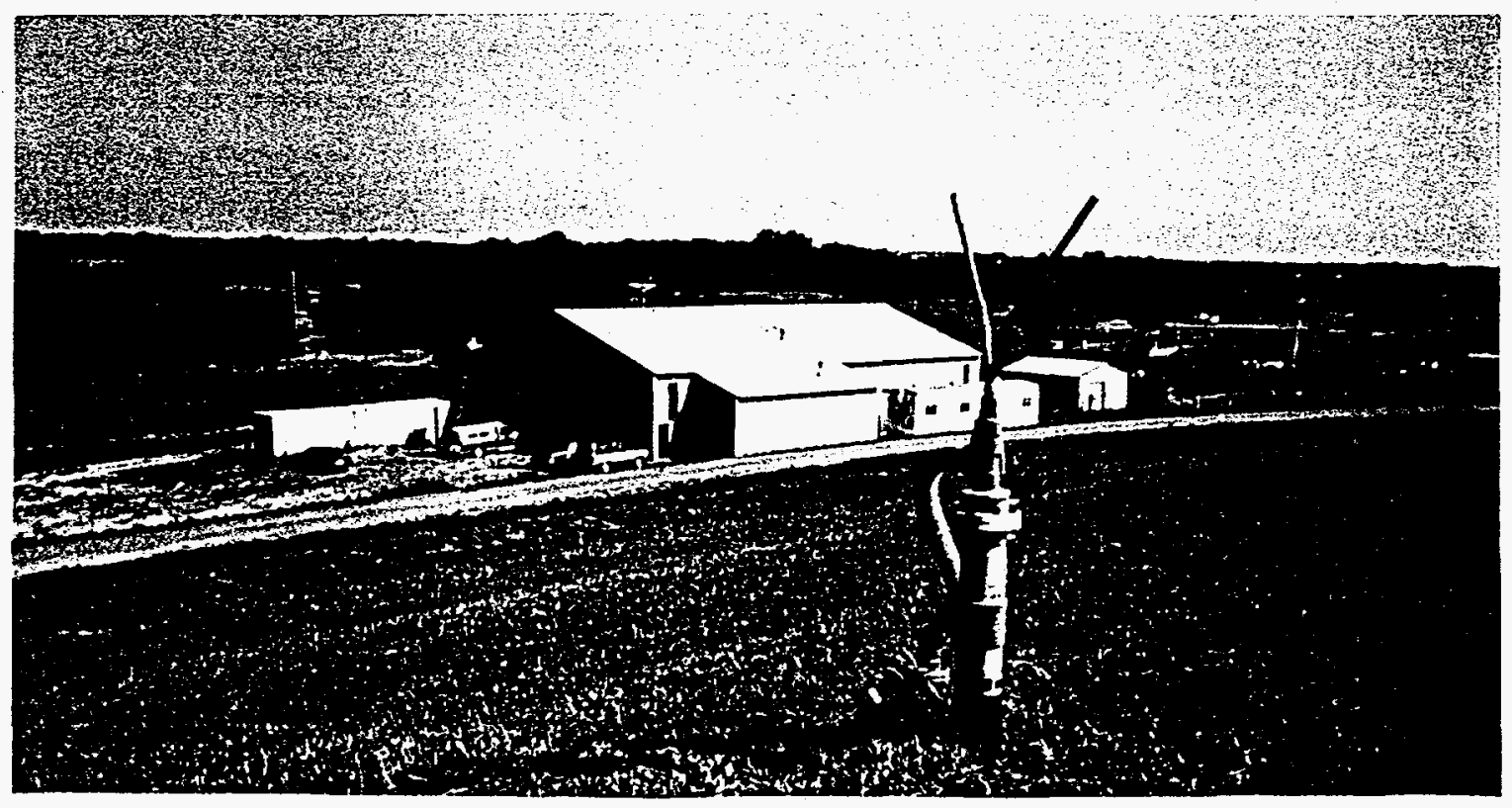

Figure 5-2 LFG CLEAN-UP TESTING FACILITY:

This facility was constructed by EPRI on the Anoka site to house the LFG cleanup system.

\subsection{TEST FACILITY AND PROCEDURES}

\subsubsection{Process Equipment}

A flow schematic which includes the major process components used during the testing reported here is shown in Figure 5-3. Landfill gas was withdrawn from the flare header and routed through approximately 130 feet $(40 \mathrm{~m})$ of $4^{\prime \prime}$, Sch. 40 PVC pipe inside the building to the gas compressor. A reciprocating compressor was used to pressurize the gas. Gas was stored in a receiver at the compressor discharge. Gas leaving the receiver passed through a mechanical regulator.

The bulk gas cleanup skid consisted of two stages: (1) bulk hydrogen sulfide removal and (2) bulk chlorinated hydrocarbon removal. Two vessels were piped in series for the bulk hydrogen sulfide removal stage. The two vessels were filled with SulfaTreat, a proprietary iron oxide formulation with a bulk density of $70 \mathrm{lb} / \mathrm{ft}^{3}\left(1,120 \mathrm{~kg} / \mathrm{m}^{3}\right)$. Two vessels were also piped in series for the bulk chlorinated hydrocarbon removal stage. These vessels were filled with activated carbon with a bulk density of $30 \mathrm{lb} / \mathrm{ft}^{3}\left(480 \mathrm{~kg} / \mathrm{m}^{3}\right)$. Valving was included such that the second vessel in each stage could be bypassed. All four of these vessels were constructed of $10 \mathrm{in}$., Sch. 40 carbon steel pipe.

Following the bulk gas cleanup skid, the gas passed through a particulate filter, metering valve, and flow meter at which point hydrogen was added (from cylinders) to the landfill gas. The mixture was heated in an electrical heater and then passed through a high-temperature reactor. 


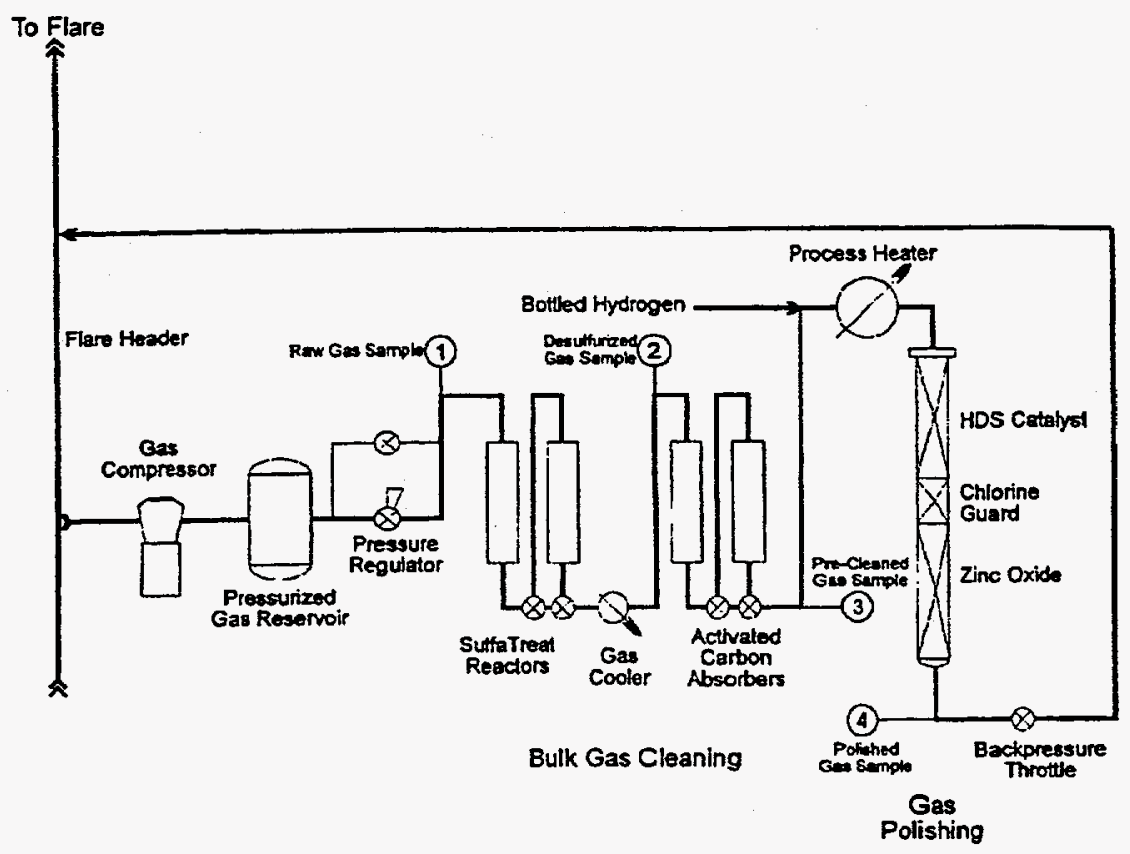

Figure 5-3 LFG GAS TREATMENT PROCESS AS TESTED AT ANOKA:

Iron oxide and activated carbon for bulk cleanup followed by hydrotreating/Cl \& $S$ capture for trace cleanup.

The high temperature reactor was constructed of 8 in., Sch. 80 SS pipe. Three solids were loaded into the high temperature reactor. The gas first came into contact (flowing downwards) with a hydrodesulfurization catalyst then a chlorine guard solid and, finally, zinc oxide. Each layer was separated from adjacent layers by approximately 3 in. $(7 \mathrm{~cm})$ of $3 / 4$ in. $(2 \mathrm{~cm})$ diameter alumina balls.

Following the high temperature reactor, the gas was throttled to near atmospheric pressure and routed back to the flare header.

\subsubsection{Data Collection Equipment and Procedures}

Standard industrial instrumentation was installed to monitor pressures, temperatures, flows, and raw gas oxygen content. These parameters were logged once an hour by plant operators. Continuous gas samples were withdrawn from the gas receiver outlet (Raw gas, Sample Point \#1, Figure 5-3) and the high temperature reactor outlet (Polished gas, Sample \#4, Figure 5-3) and analyzed by gas chromatograph.

Trace gas samples were grabbed for analysis on a daily basis. Table 5-1 provides the collection/analytical procedure used for each contaminant quantified. 
Table 5-1 SAMPLING AND ANALYTICAL PROCEDURES:

These methods were used by interpoll Laboratories.

\begin{tabular}{|l|c|l|}
\hline \multicolumn{1}{|c|}{ CONTAMINANT(S) } & $\begin{array}{c}\text { SAMPLING POINTS } \\
\text { (Figure 5-1) }\end{array}$ & \multicolumn{1}{|c|}{$\begin{array}{c}\text { COLLECTION/ANALYTICAL } \\
\text { PROCEDURE }\end{array}$} \\
\hline Hydrogen Sulfide & $1,2,3,4$ & Modified EPA Method 11 \\
\hline $\begin{array}{l}\text { Methyl Mercaptan } \\
\text { Dimethyl Sulfide }\end{array}$ & $1,3,4$ & $\begin{array}{l}\text { Standard GC/flame photometric detector on } \\
\text { samples collected in virgin Tedlar bags }\end{array}$ \\
\hline Sulfur Dioxide & $1,3,4$ & EPA Method 6 \\
\hline $\begin{array}{l}\text { Chlorinated Organic } \\
\text { Compounds }\end{array}$ & $1,3,4$ & TO-14, samples collected in virgin Tedlar bags \\
\hline $\begin{array}{l}\text { Hydrogen Chloride } \\
\text { Hydrogen Fluoride }\end{array}$ & 4 & EPA Method 26 \\
\hline $\begin{array}{l}\text { Volatile Silica } \\
\text { Compounds }\end{array}$ & 1 & Dow Chemical Method CTM 1123 \\
\hline SulfaTreat solids & profile & ASTM Method D3682 \\
\hline
\end{tabular}

\subsection{HOUR LFG CLEANUP TEST AT ANOKA}

\subsubsection{Operational History}

Preliminary testing was undertaken December 4,5 , and 7,1995 . During these three days, approximately $15,000 \mathrm{scf}\left(425 \mathrm{Nm}^{3}\right)$ of landfill gas passed through the entire gas cleanup apparatus for approximately 15 hours. This period was used to shakedown the equipment and identify deficiencies that could not be observed short of actual operation. There was no hydrogen injection during this initial 15 hours of operation nor were gas samples taken for either bulk gas analysis or trace gas analysis. Operational parameters were logged. The primary result of this initial effort was to identify the need for additional insulation on several of the landfill gas lines and the need for some remedial work on heat tracing.

More rigorous testing began on February 12, 1996. After purging the piping with bottled nitrogen, a nitrogen flow of approximately $120 \mathrm{scfh}\left(3.4 \mathrm{Nm}^{3} / \mathrm{hr}\right)$ was established from just upstream of the flow metering equipment through to the flare header. This flow was used to heat up the solids in the gas polishing stage.

When the temperature of the gas entering the polishing stage reached $450^{\circ} \mathrm{F}$ $\left(230^{\circ} \mathrm{C}\right)$, a mixture of $3.5 \%$ hydrogen sulfide in nitrogen was also added to the main nitrogen flow to pre-sulfide the hydrodesulfurization catalyst as recommended by the catalyst supplier. Approximately $285 \mathrm{scf}\left(8.1 \mathrm{Nm}^{3}\right)$ of this mixture was added to the gas stream over a 20 hour period. Three hours after the hydrogen sulfide flow stopped, the outlet temperature of the gas polishing stage was sufficiently high to allow introduction of landfill gas. 
Landfill gas began flowing through the system at 9:30 AM on February 14 at a rate between 950 and $1000 \mathrm{scfh}\left(27-28 \mathrm{Nm}^{3} / \mathrm{hr}\right)$. Hydrogen flow was also established at this time. The following are the critical operational parameters and the methods the operators used to control the parameters for the remainder of the test:

- $\quad$ SulfaTreat reactor temperature - The target temperature for the SulfaTreat reactors was $140^{\circ} \mathrm{F}\left(60^{\circ} \mathrm{C}\right)$. The gas temperature leaving the landfill gas compressor was in excess of $280^{\circ} \mathrm{F}\left(140^{\circ} \mathrm{C}\right)$. The relatively low gas flow rate, however, resulted in high conduction losses through the piping and vessel walls. At the beginning of the test the only control over the vessel temperatures was to control the heat loss in the piping upstream of the reactors. This proved to be less than satisfactory during the first several hundred hours of testing; outlet temperatures were chronically lower than the desired $140^{\circ} \mathrm{F}\left(60^{\circ} \mathrm{C}\right)$. Additional insulation was applied to the inlet piping and vessels in late February. This helped stabilize the inlet temperature, but the outlet temperature remained chronically low. Heat tracing was added to the inlet piping and vessels and, from March 4 on, the outlet temperature was within $20^{\circ} \mathrm{F}$ $\left(11^{\circ} \mathrm{C}\right)$ of the inlet temperature. Both of these temperatures tended to follow the ambient temperature.

$\cdot$

Activated carbon absorber temperature - No direct control was exerted over the activated carbon bed temperatures. Gas temperatures entering the activated carbon beds were $15-25^{\circ} \mathrm{F}\left(8-14^{\circ} \mathrm{C}\right)$ lower than the SulfaTreat outlet temperatures. The activated carbon beds remained uninsulated throughout the testing.

- $\quad$ Gas polishing stage temperature - The inlet temperature of this stage was easily maintained at or above the target level by adjusting the output of the upstream electric heater and the electric heat tracing on the inlet piping. The outlet temperature was chronically lower during the entire test. During the first few weeks of testing, the outlet temperature was approximately $90^{\circ} \mathrm{F}\left(50^{\circ} \mathrm{C}\right)$ lower than the inlet. After additional insulation was added to the outside of the vessel, the outlet temperature rose to within $60^{\circ} \mathrm{F}\left(33^{\circ} \mathrm{C}\right)$ of the inlet. Electrical heat tracing surrounding the vessel was operated at $100 \%$ output during the entire test.

Landfill gas pressure and flow - The target landfill gas pressure was 30 psig (2.1 bar) at a flow of $970 \mathrm{scfh}\left(27.5 \mathrm{Nm}^{3} / \mathrm{hr}\right)$. As the waste gas header just upstream of the flare operated at near atmospheric pressure, a throttling valve downstream of the gas polishing stage was used to maintain a high back pressure in the absorbers. At the front end of the system, the mechanical regulator at the discharge of the landfill gas compressor was found to be undersized. In order to get the target flow, the bypass around this regulator was partially opened. This caused the downstream pressure to fluctuate 4-5 psig (0.3-0.4 bar) as the compressor discharge pressure fluctuated between 54 and $42 \mathrm{psig}$ ( 3.7 and $2.9 \mathrm{bar}$ ). Fine control over the landfill gas flow was achieved by automatically adjusting the gas pressure at the landfill gas flow meter.

- Hydrogen flow - Hydrogen flow rate was adjusted to maintain a hydrogen 
concentration at the gas polishing stage outlet as measured by the bulk gas chromatograph. This was achieved by adjusting a needle valve just downstream of a mechanical regulator. This needle valve operated under choked conditions, so flow was independent of downstream pressure. The valve position and regulator setting were not changed substantially during the duration of testing. Thus, the hydrogen flow rate was essentially constant throughout the test.

The landfill gas flow during operations in February and March 1996 is shown in Figure 5-4. Gas flow was at target levels for the entire period with three exceptions.

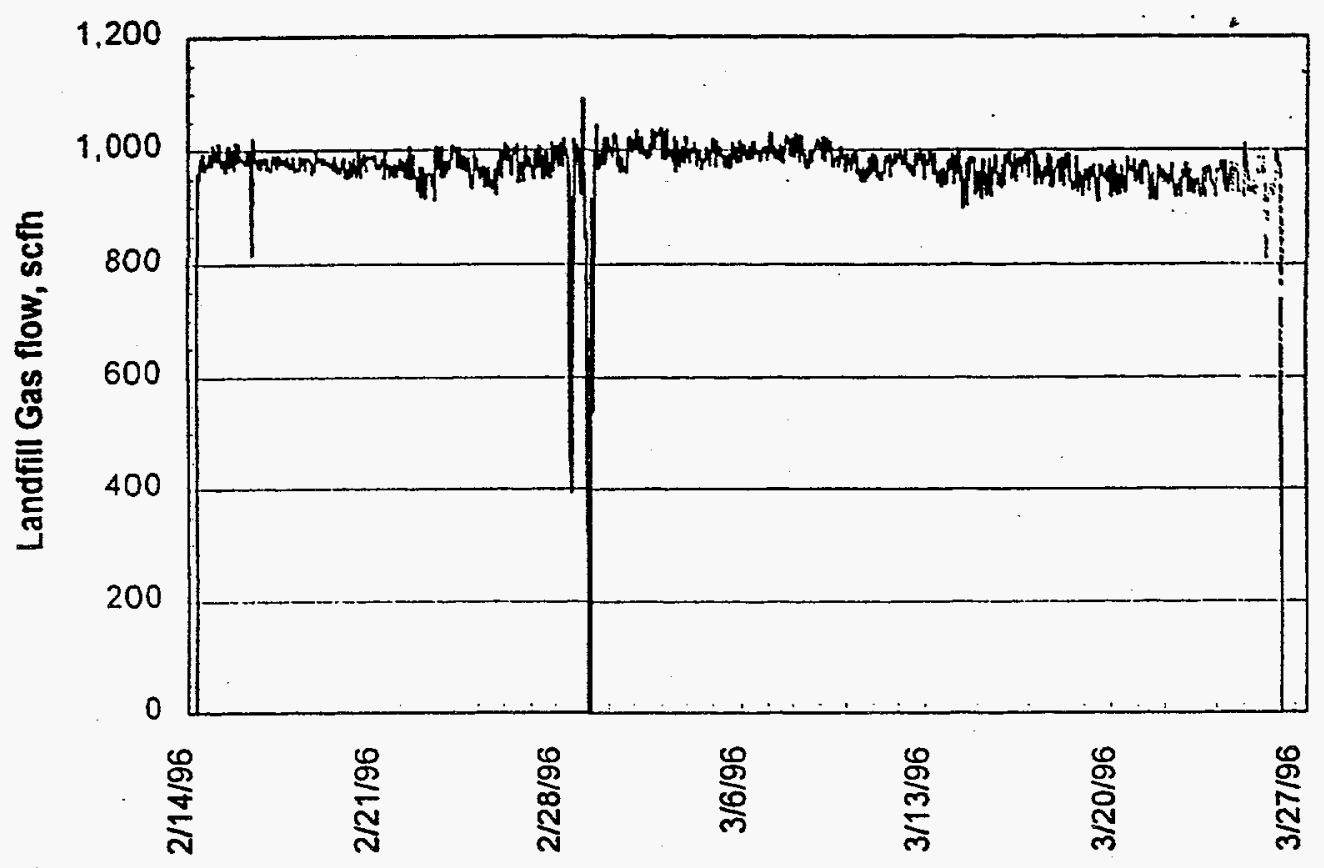

Figure 5-4 GAS TREATMENT PROCESS TESTING LANDFILL GAS FLOW:

LFG Gas flow of $970 \mathrm{scfh}$ was maintained with three exceptions.

During the morning of February 16, gas flow fell approximately $20 \%$. Inspection of pressure gauges throughout the system indicated that the restriction was between the activated carbon beds and the flow meter. Ice buildup was suspected. After two hours of reduced flow, the flow rose back up to target levels without intervention.

Severely cold weather during the evening of February 28 and the morning of February 29 caused water to condense in the line between the activated carbon vessels and the pressure regulating valve just upstream of the flow meter. This condensate collected in a low spot in the piping and froze, eventually blocking off the flow. Flow was reestablished by heating the piping in this area to melt the plug and then draining the water from the low spot. Condensed water was drained from this point daily through the end of the test. 
Another spell of cold weather caused some freezing to occur in the activated carbon vessel on the last day of testing. This caused a minor reduction in gas flow the morning of the last day. No remedial actions were taken as the test was completed.

Operations in February and March were divided into three phases, as indicated in Table 5-2. These phases are defined by the amounts of adsorbents through which the gas flowed.

Table 5-2 LANDFILL GAS TREATMENT TESTING, OPERATIONAL PHASES:

Reduction in the number of iron oxide and carbon beds in service provided more rapid breakthrough.

\begin{tabular}{|c|c|c|c|c|}
\hline PHASE & $\begin{array}{l}\text { ABSORBERS } \\
\text { IN SERVICE }\end{array}$ & OPERATING PERIOD & $\begin{array}{c}\text { OPERATING } \\
\text { HOURS }\end{array}$ & $\begin{array}{l}\text { TOTAL GAS } \\
\text { FLOW, } \\
\text { SCF }\left(\mathrm{NM}^{3}\right)\end{array}$ \\
\hline 1 & $\begin{array}{c}2 \text { Sulfa Treat } \\
2 \text { Activated Carbon }\end{array}$ & $\begin{array}{l}\text { Beginning of the test through } \\
11: 30 \text { am, } 2 / 24 / 96\end{array}$ & 258 & $251,000(7,110)$ \\
\hline 2 & $\begin{array}{c}1^{\text {st }} \text { Sulfa Treat } \\
1^{\text {st }} \text { Activated Carbon }\end{array}$ & $\begin{array}{c}11: 30 \text { am, } 2 / 24 / 96 \\
\text { to } \\
10: 30 \text { am. } 3 / 14 / 96\end{array}$ & 455 & $443,000(12,550)$ \\
\hline 3 & $\begin{array}{c}2 \text { Sulfa Treat } \\
1^{\text {st }} \text { Activated Carbon }\end{array}$ & $\begin{array}{l}10: 30 \mathrm{am}, 3 / 14 / 96 \\
\text { to end of the test }\end{array}$ & 289 & $276,000(7,820)$ \\
\hline
\end{tabular}

The change from Phase 1 to Phase 2 was undertaken to hasten the breakthrough of contaminants in the respective bulk gas cleaning absorbers. The change from Phase 2 to Phase 3 was made when measurements indicated significant amounts of hydrogen sulfide were breaking through the single SulfaTreat vessel. The gas polishing stage was fully in service during all testing.

During the test period, landfill gas was moved through the three-stage gas cleanup system for 1002 hours at an overall average rate of $968 \mathrm{scfh}\left(27.4 \mathrm{Nm}^{3} / \mathrm{hr}\right)$. In excess of $970,000 \operatorname{scf}\left(27,500 \mathrm{Nm}^{3}\right)$ of landfill gas was cleaned.

\subsubsection{Bulk Gas Chromatograph Operation}

The bulk gas chromatograph was in operation during the February-March testing. Standard operation was to alternate between the raw gas and polished gas samples. It was found that the carbon dioxide determination was the least precise determination. Calibrations for all other gases were found to be very consistent from day to day while the carbon dioxide calibration was inconsistent. Thus, the carbon dioxide analyses reported here are all calculated by subtracting the remaining analyses from $100 \%$. Less than $10 \%$ of the gas analyses (primarily towards the beginning of the test period) were rejected for one or more of the following reasons: 
- Uncorrected measurement of total gas \% was greater than $120 \%$ or less than $80 \%$.

- Measured carbon dioxide differed from calculated carbon dioxide by more than 10 percentage points.

- Oxygen content was greater than $2 \%$ (indicating contamination of the gas sample with air).

During the first two weeks of testing, $\mathrm{C}_{2^{-}}, \mathrm{C}_{3^{-}}, \mathrm{C}_{4^{-}}$and $\mathrm{C}_{5^{-}}$aliphatic hydrocarbons were included in the bulk gas analysis routine. None of these hydrocarbons were present in significant quantities with normal analysis reports less than $0.001 \%$ and never exceeding $0.017 \%$. For this reason, they were deleted from the analysis routine on February 29. This reduced the time between analyses at either sample point from 66 minutes to 31 minutes.

On two occasions the polished gas sampling line froze. When the sample pump at the chromatograph then drew sample from this line, it took air back through the sample gas vent. These occasions were obvious from the high oxygen contents reported. Otherwise, the oxygen content was less than about $1.5 \%$ for both raw gas and polished gas.

Figures 5-5 and 5-6 show the raw gas analyses and polished gas analyses, respectively, over the duration of test. The following are notable about this data:

- The oxygen in the raw gas is not an artifact of the sampling/analysis. A polarigraphic oxygen analyzer was used to analyze the oxygen content of the gas just downstream of the SulfaTreat absorber. Throughout the test this instrument indicated oxygen contents in the gas consistent with the concentrations reported by the gas chromatograph. Some, but not all, of this oxygen penetrated the gas polishing stage. (Note that oxygen concentration is tracked by nitrogen concentration indicating that the oxygen comes from air leaks. Portions of the landfill gas collection system operate at slight vacuum which allows air to leak into the collection system.)

- The raw gas contained no carbon monoxide. The polished gas contained a few percent carbon monoxide. This carbon monoxide was produced in the polishing reactor by the reverse water-gas shift reaction:

$$
\mathrm{CO}+\mathrm{H}_{2} \mathrm{O}=\mathrm{CO}_{2}+\mathrm{H}_{2}
$$

\subsubsection{Trace Gas Contaminant Sampling}

\section{Gas Phase Sulfur}

The hydrogen sulfide concentrations in the raw gas averaged about $40 \mathrm{ppmv}$ through the 1000 hours of testing. The SulfaTreat sorbent was able to reduce the hydrogen sulfide concentration below detectable limits $(80 \mathrm{ppbv})$ throughout the early 


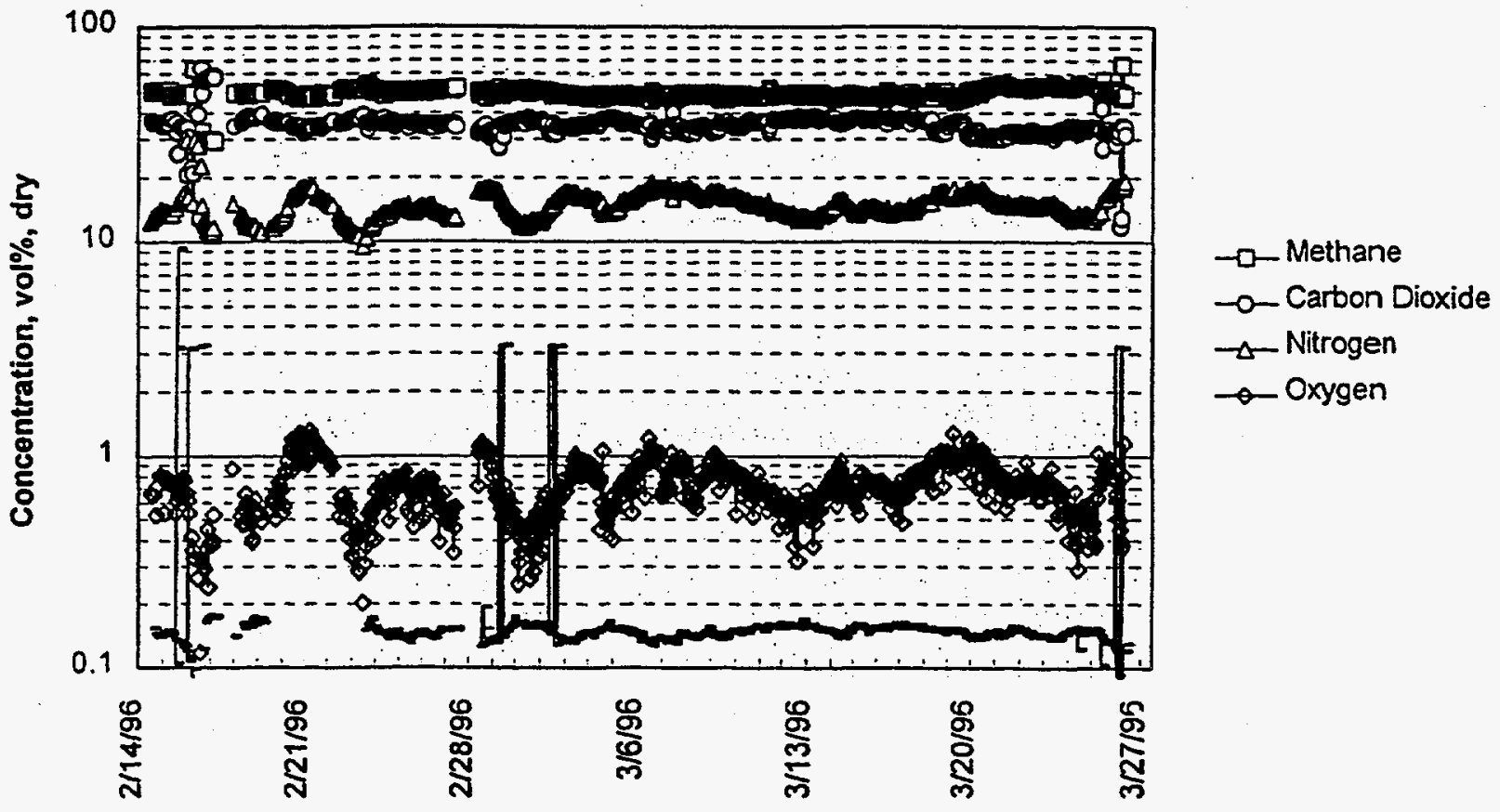

Figure 5.5 RAW LANDFILL GAS BULK COMPOSITION:

LFG gas composition shows fluctuations in $\mathrm{N}_{2}$ and $\mathrm{O}_{2}$ indicating air leakage.

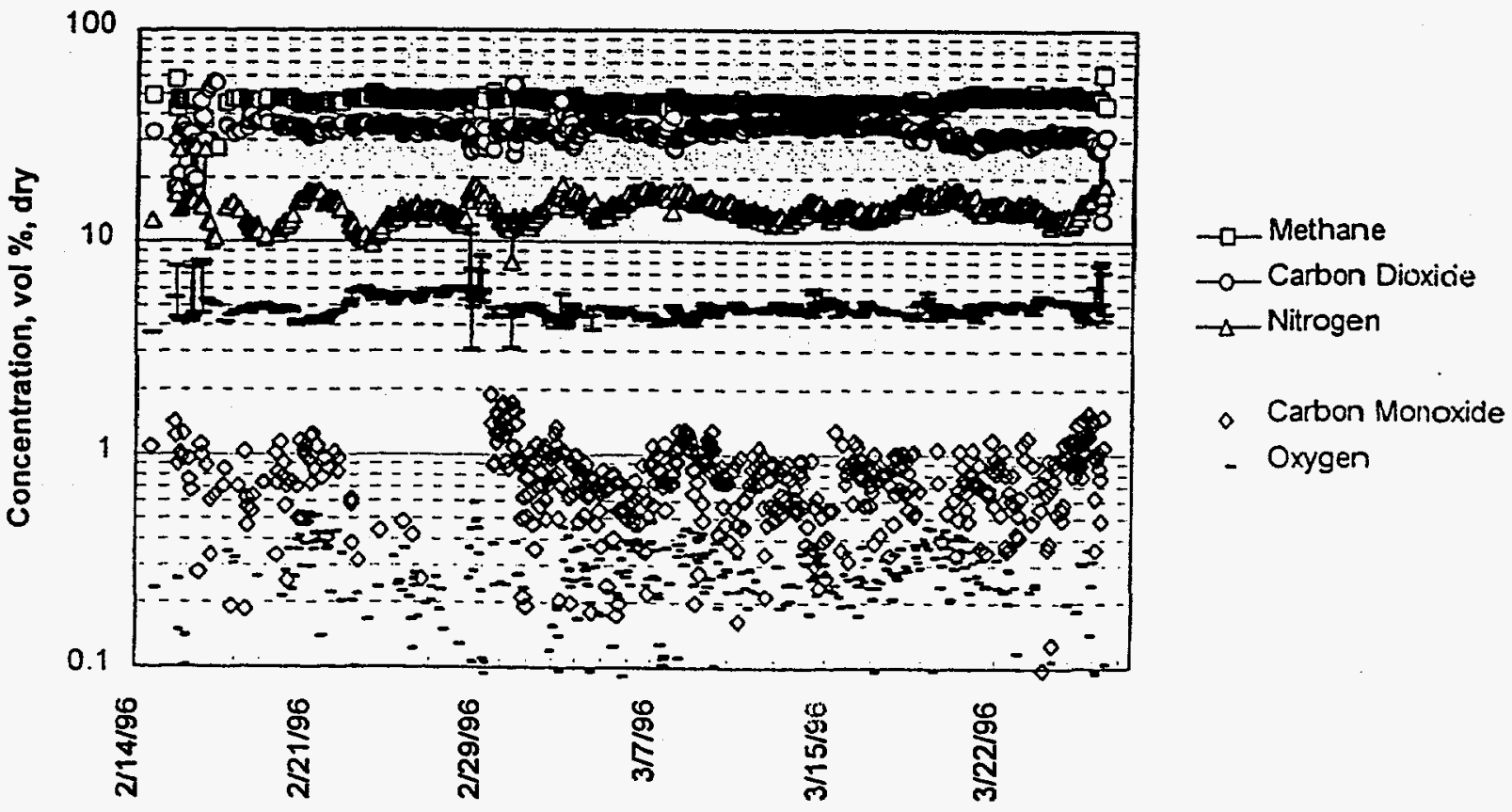

Figure 5-6 POLISHED LANDFILL GAS BULK COMPOSITION:

Oxygen levels reduced to about $0.2 \%$ by the cleanup system. 
testing. The hydrogen sulfide concentrations measured during the test period are shown in Figure 5-7. (Data were taken each day. Missing data points in the March 13-20 period are for analyses which indicated hydrogen sulfide concentrations less than 2,700 ppbv, the lower detection limit for the analysis procedure used on these samples.)

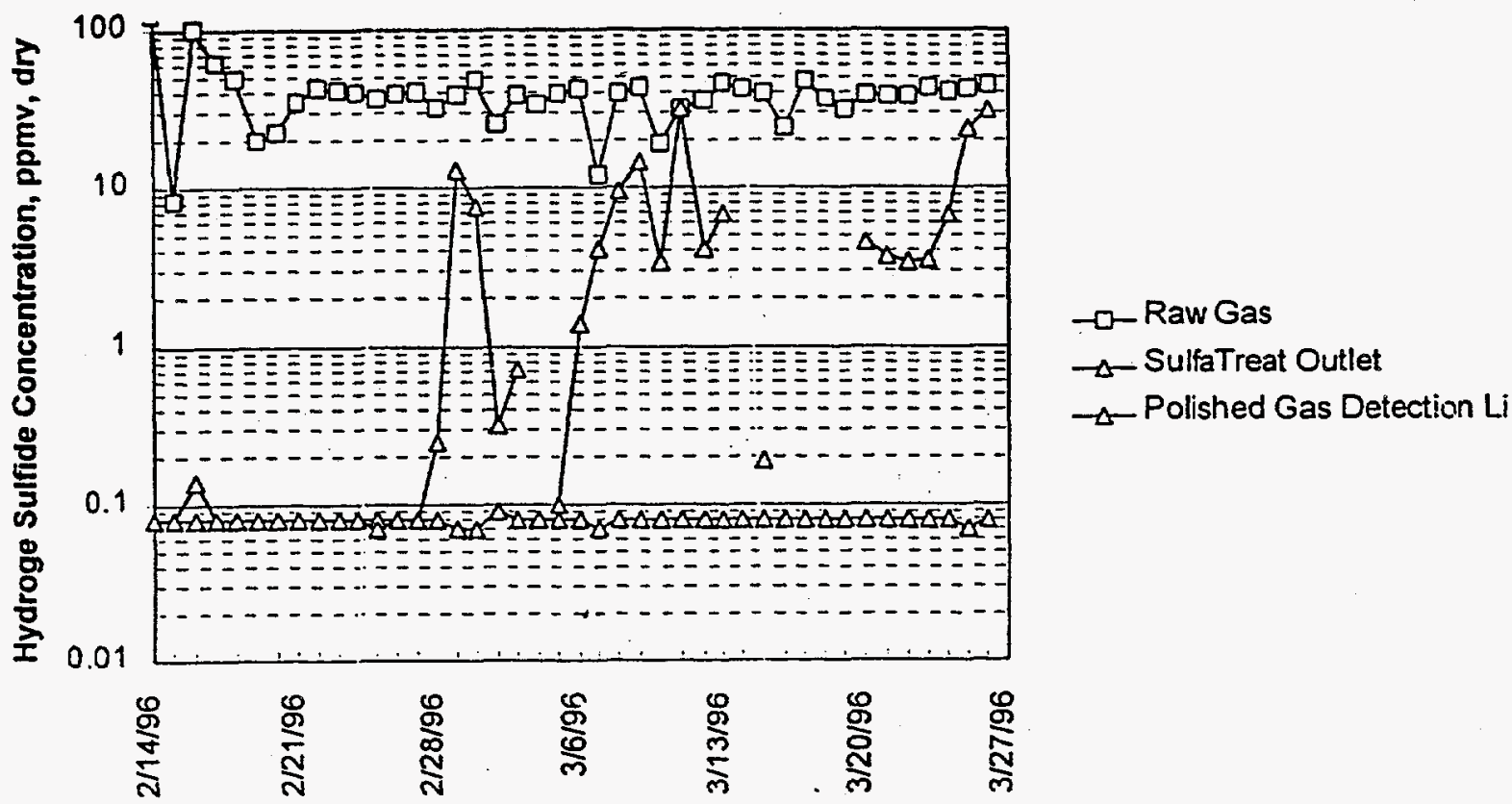

Figure 5-7 HYDROGEN SULFIDE CONCENTRATIONS:

Two SulfaTreat columns in service through $2 / 24$, One column in service $2 / 24-3 / 14$, two columns in service $3 / 14$ - end of test.

After 258 hours of operation, the second SulfaTreat vessel was taken out of service to reduce the time to breakthrough. Hydrogen sulfide broke through the first SulfaTreat bed after approximately 360 hours of operation during a period when ambient temperatures were particularly cold and the SulfaTreat bed temperatures dropped to under $100^{\circ} \mathrm{F}\left(38^{\circ} \mathrm{C}\right)$. After remedial actions were taken to raise the bed temperatures, the outlet hydrogen sulfide concentration dropped again to the $100 \mathrm{ppbv}$ level. Hydrogen sulfide broke through the first SulfaTreat bed permanently after approximately 520 hours of operation. When the second SulfaTreat column was returned to service after 713 hours of operation, hydrogen sulfide concentrations dropped again below 2,000 ppbv. Breakthrough of the second SulfaTreat column occurred after approximately 860 hours of operation as hydrogen sulfide concentrations rose to levels near 5,000 ppbv and then to levels near $20,000 \mathrm{ppbv}$ at 950 hours of operation.

The methyl mercaptan and dimethyl sulfide concentrations measured are shown in Figures 5-8 and 5-9, respectively. The methyl mercaptan concentration in the raw gas averaged just under 2,000 ppbv while the dimethyl sulfide concentration in the raw gas averaged 3,000-4,000 ppbv. Methyl mercaptan was captured by the SulfaTreat/activated carbon and never broke through during the 1000 hours of testing. Dimethyl sulfide broke through the SulfaTreat/activated carbon within 10 days. Neither compound was found in measurable quantities in the polished gas; the hydrodesulfurization stage was effective. 


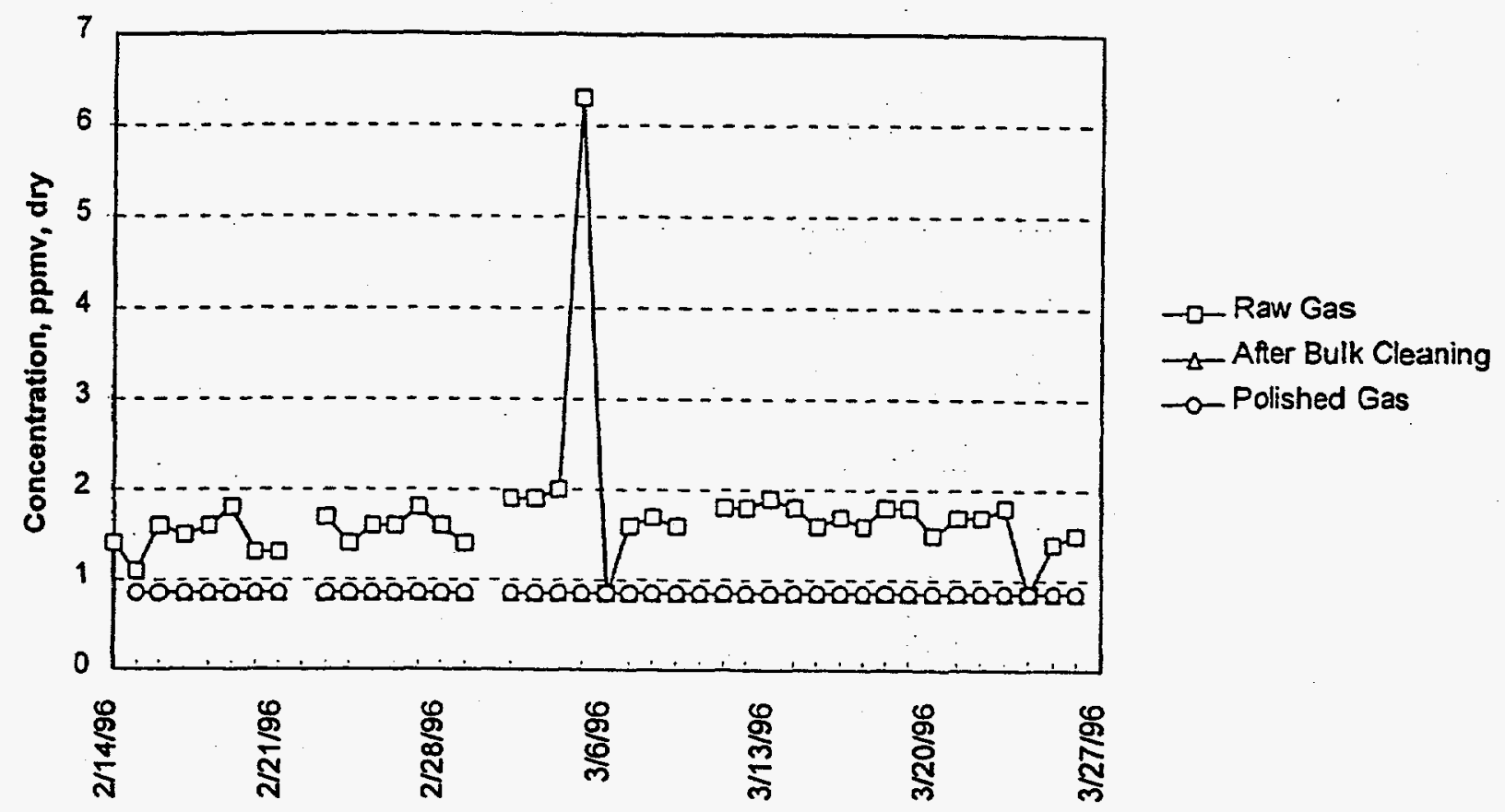

Figure 5-8 METHYL MERCAPTAN CONCENTRATIONS:

Methyl mercaptan remained below detection limits after bulk cleanup and final cleanup.

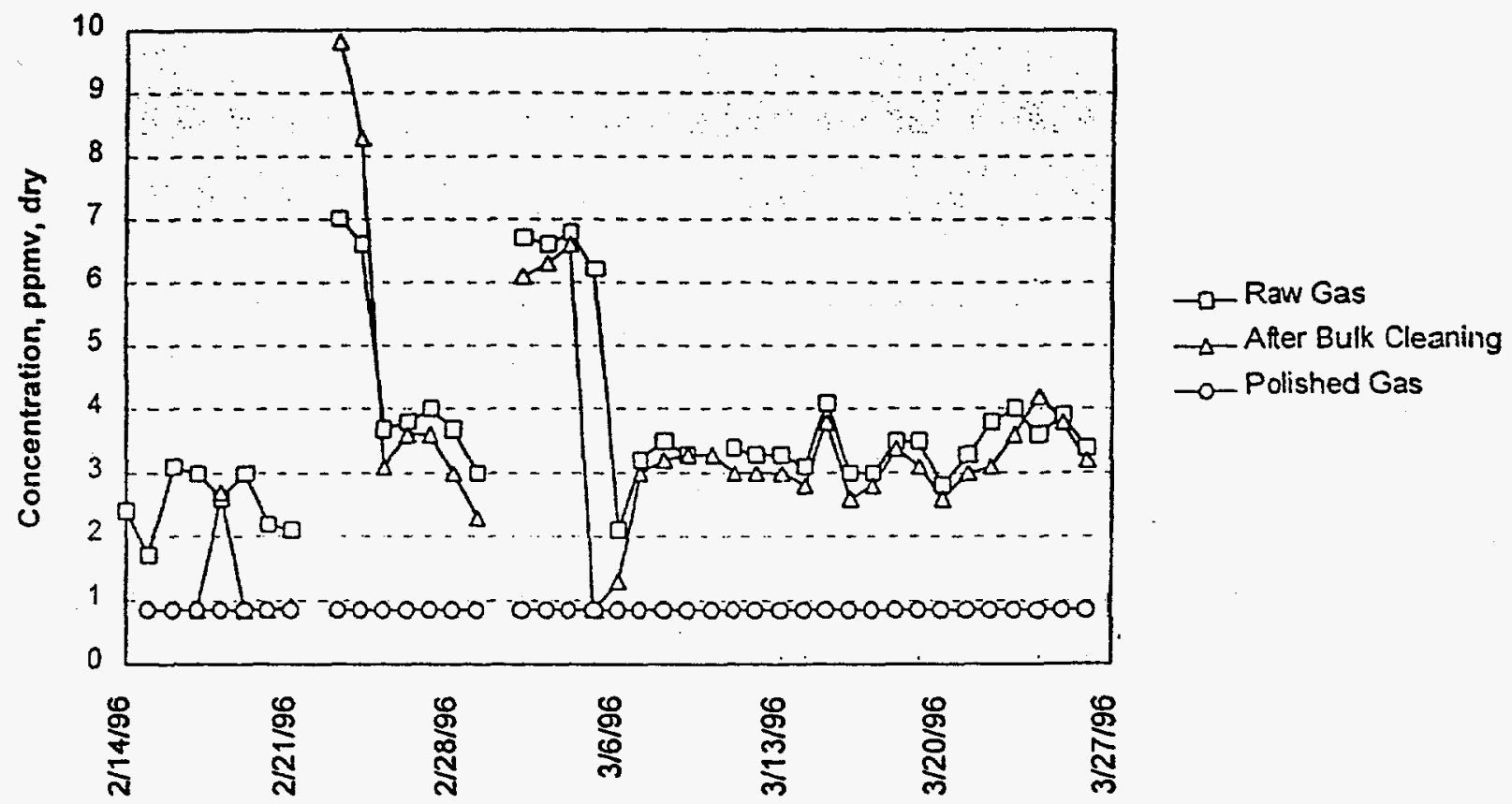

Figure 5-9 DIMETHYL SULFIDE CONCENTRATIONS:

DMS was not effectively removed by the iron oxide/carbon beds, but was removed by the final cleanup. 
When early testing indicated that oxygen was present in the raw gas, the sulfur dioxide content of several randomly-drawn samples was measured. It was found that the raw gas contained $4,000-6,000$ ppbv sulfur dioxide. The bulk gas cleaning stage (SulfaTreat/activated carbon) reduced the concentrations to $2,000-5,000 \mathrm{ppbv}$. The gas polishing stage (hydrogenation/-chloride removal/sulfide removal) further reduced the concentrations to 1,000-2,000 ppbv. These polished gas levels are, however, greater than the target $100 \mathrm{ppbv}$ for gas phase sulfur. Trace $\mathrm{SO}_{2}$ removal, therefore, remains an objective for future LFG cleanup efforts.

\section{SulfaTreat Sorbent Sulfur Loading}

Samples of the SulfaTreat solids were taken at the end of the test after 1002 hours. The sulfur content of the SulfaTreat at the entrance to the $1^{\text {st }}$ vessel (exposed to greatest sulfur concentrations) was $10.7 \mathrm{wt} \%$ (dry, ignited basis).

\section{Chlorinated Hydrocarbons/Hydrogen Chloride}

Concentrations of 29 chlorinated hydrocarbons and concentrations of 8 aromatic compounds are summarized in Figure 5-10. For each compound listed in this figure, three data points are shown as follows:

Top Line: The average raw gas concentration over the entire test.

Middle Line: The average concentration leaving the activated carbon beds after the carbon had been saturated with the compound. This is very near the raw gas concentration for most of the compounds.

Bottom Line: The average concentration in the polished gas over the entire test.

The column of numbers at the right of the figure indicate the number of days after which the concentration at the outlet of the activated carbon bed reached the level indicated by the middle line for each compound. This is a measure of the time to breakthrough for each compound. The following is notable about this data:

- Approximately half of the chlorinated hydrocarbons tested for were found in measurable quantities in the raw gas.

- The only chlorinated compound to be effectively captured by the activated carbon (break-through time $>20$ days) was 1,2 dichlorobenzene. Vinyl chloride (chloroethene) broke through in less than 5 days. The remaining compounds broke through in less than 10 days.

- The polished gas contained no chlorinated hydrocarbons in concentrations above the detection limit of approximately 20 ppbv ( 80 ppmv for dichloromethane). 
Concentration, ppbv

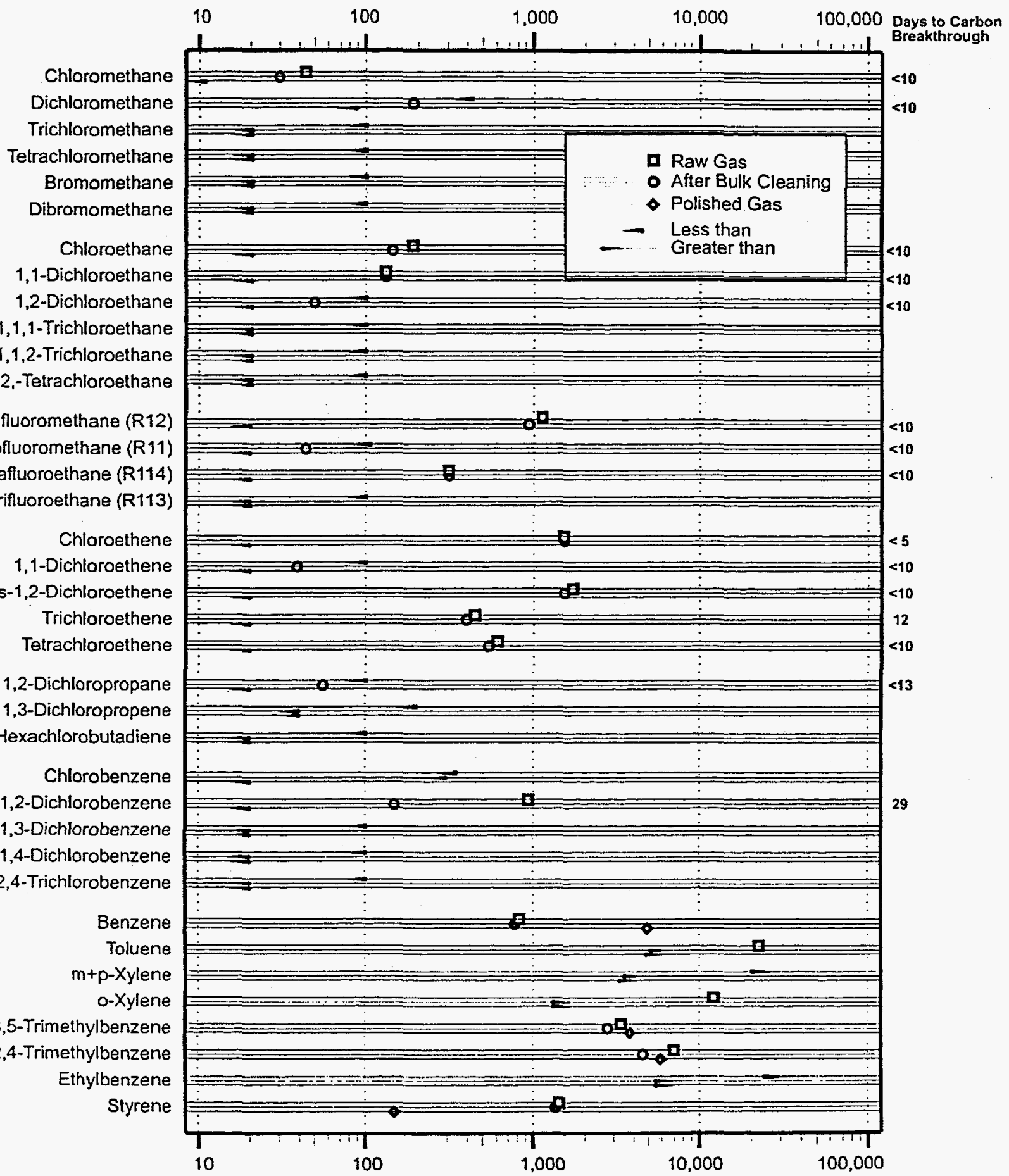

Figure 5-10 CHLORINATED HYDROCARBON CONCENTRATION DATA SUMMARY:

Chlorinated hydrocarbon were reduced to $20-80 \mathrm{ppb}$ by the cleanup system. 
Hydrogen chloride concentrations in the polished gas were measured on March 8 , 9 , and 10 . None of these measurements showed hydrogen chloride concentrations to be above the detection limit of approximately $300 \mathrm{ppbv}$.

\section{High Temperature Solid Sorbents}

At the end of the testing period, samples of the high-temperature solids were taken for analysis. There was clearly some cross-mixing of the solids during operation and as solids were removed from the reactor. Nonetheless, the following observations are valid:

- The low levels of organic sulfur and hydrogen sulfide (10,000-15,000 ppbv) entering the HDS reactor served to continue the catalyst sulfiding process. Gas phase sulfur did not, apparently, leave the HDS catalyst bed. The sulfur loading on the HDS catalyst at the end of the test was about $2.5 \%(\mathrm{w} / \mathrm{w})$, up from $1.4 \%(\mathrm{w} / \mathrm{w}$, calculated) after pre-sulfiding with bottled hydrogen sulfide. In commercial refinery practice, the HDS catalyst will take up gas phase sulfur until the sulfur content of the HDS catalyst bed is as much as $8-12 \%(w / w)$. The low sulfur loading on the zinc oxide $(<0.05 \% \mathrm{w} / \mathrm{w})$ at the end of the test confirms that essentially no sulfur left the HDS reactor. The sulfur content of the HDS catalyst would have reached a steady state value during a longer-term test. Under these conditions, gas phase sulfur (hydrogen sulfide) would penetrate the HDS catalyst bed and be picked up by the zinc oxide.

- Contamination of the HDS catalyst by chlorides was relatively low at less than 800 ppmw. This level of chlorine contamination on the catalyst did not have a measurable effect on catalyst activity.

- The chlorine guard had a chloride loading of approximately $10 \%(\mathrm{w} / \mathrm{w})$ at the end of the test. According to the supplier, this chlorine guard has a capacity of up to $19 \%(w / W)$ at breakthrough and was, therefore, only about $50 \%$ loaded at the end of the test period. 


\subsection{FUEL CELL TESTING ON SIMULATED LANDFILL GAS}

Fuel cell testing was conducted at Energy Research Corporation using simulated LFG composition typical of the Anoka site. Major gas components without contaminants were used in this test. A $32 \mathrm{~kW}$ carbonate fuel cell stack (AF-20-6) was used in the simulated landfill gas study, as shown in Figure 6.1. The stack was comprised of 68 cells and 9 reforming units of $2^{\prime} \times 3^{\prime}$ size. All of the repeating components were made at ERC's manufacturing subsidiary, Fuel Cell Manufacturing Corporation (FCMC).



Figure 6-1 32kW CARBONATE FUEL CELL STACK TESTED ON SIMULATED LFG:

525 hours of operation on simulated LFG completed.

The simulated landfill gas test followed conditioning and qualification testing, followed by operation on reformed diesel fuel and jet fuel (logistic fuels). Operation on logistic fuels was carried out for 720 hours.

\subsection{SIMULATED LANDFILL GAS OPERATION}

Based on the Anoka gas cleanup field test, the Anoka landfill gas composition was used to simulate fuel cell performance, as shown in Figure 6-2. The LFG enters the fuel cell power plant which includes a pre-reformer to reform higher hydrocarbons. The equilibrium composition leaving the pre-reformer enters the fuel cell. This composition, which is derived from the Anoka LFG composition, is shown in Table 6-1, along with the calculated oxidant composition. 


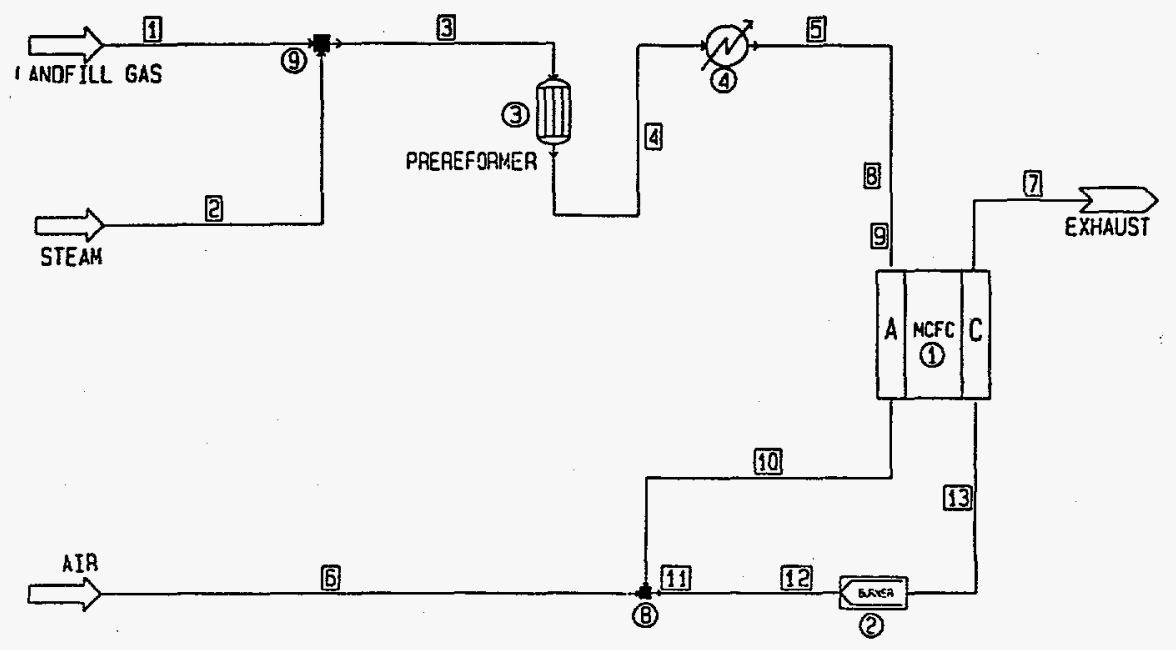

FILE- LFSTKS3

\begin{tabular}{|lr|}
\hline Equip. No. & 1 \\
Reforming Temp. C & 632.2200 \\
Fuel Utilization (\%) & 0.6955 \\
Oxygen Utilization (\%) & 0.2325 \\
Cell area cm $\mathrm{cm}^{2}$ & 4700.0000 \\
Number of Cells & 68.0000 \\
Current Density ( A/cm²) & 0.1333 \\
Power (kw) & 31.9904 \\
Cell Voltage (volt) & 0.7509 \\
\hline
\end{tabular}

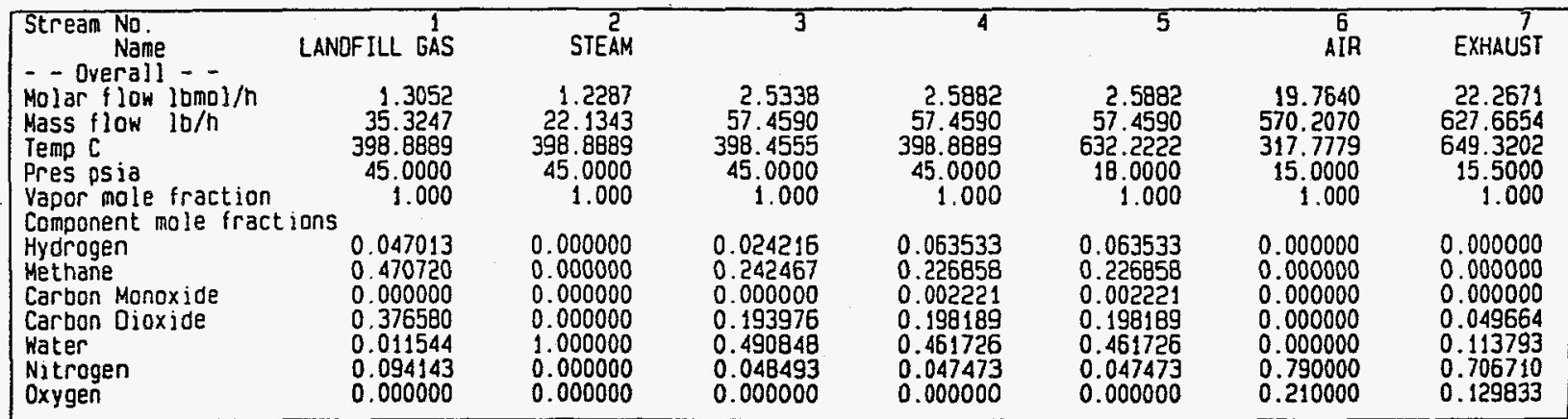

Figure 6-2 SIMULATED FUEL CELL PERFORMANCE ON ANOKA LANDFILL GAS:

Good performance is achieved On LFG. 
Table 6-1. SIMULATED LANDFILL GAS COMPOSITIONS:

Fuel cell system compositions based on the Anoka LFG composition.

\begin{tabular}{|l|c|c|}
\hline \multirow{2}{*}{\multicolumn{2}{c|}{ COMPONENT }} & \multicolumn{2}{c|}{ GAS COMPOSITION, vol \% } \\
\cline { 2 - 3 } & FUEL & OXIDANT \\
\hline Hydrogen & 6.4 & -- \\
\hline Oxygen & -- & 15.1 \\
\hline Nitrogen & 4.7 & 63.2 \\
\hline Methane & 22.7 &.-- \\
\hline Carbon Dioxide & 19.8 & 11.5 \\
\hline Carbon Monoxide & 0.2 & -- \\
\hline Water & 46.2 & 10.2 \\
\hline
\end{tabular}

Following the full load performance verification, the stack was operated at a lower load $\left(80 \mathrm{~mA} / \mathrm{cm}^{2}\right)$ generating $20 \mathrm{~kW}$ of power for a 500 -hour endurance test. The endurance history is shown in Figure 6-3. Stack performance remained stable throughout the endurance test.

There were two interruptions in which the facility safety circuit tripped and placed the stack in standby mode. They were the result of erratic readings from the facility related equipment and were not due to stack performance. In addition, the stack was also placed in standby mode as a result of a delayed fuel gas delivery to ERC.

The stack operated at the endurance conditions for approximately 525 hours. The stack load was increased to the full load conditions prior to the endurance test. A polarization curve on LFG is shown in Figure 6-4 which shows that performance exceeds slightly the performance predicted by simulation, and that a small derating compared to natural gas is obtained. The test results indicate that LFG operation closely matches predictions, and results in good performance on LFG. 


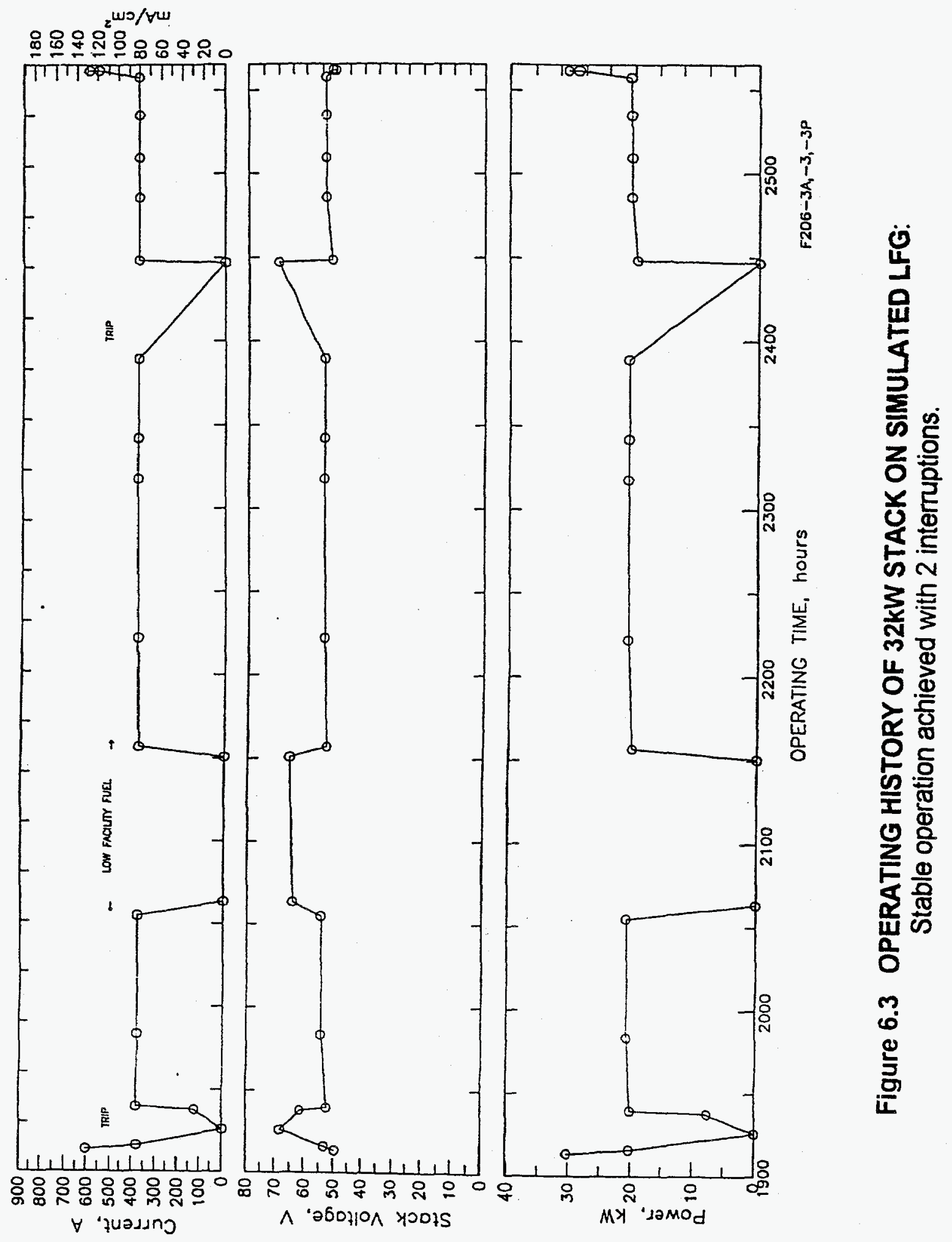




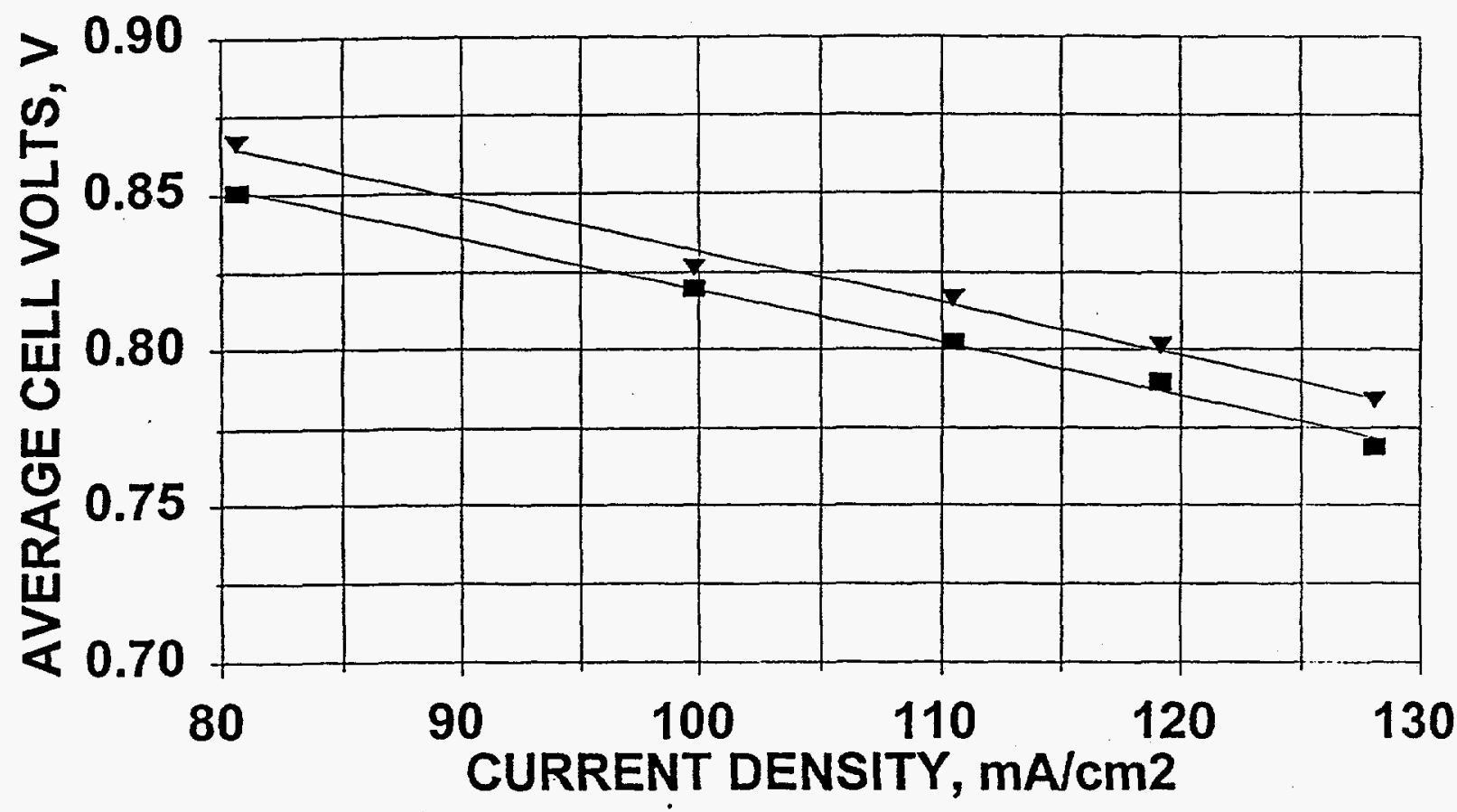

- SIM. LFG $\checkmark$ SCDP/5NRS (Natura1

Figure 6.4 32kW STACK TEST ON LFG COMPARED TO NATURAL GAS: Operation on LFG results in slightly lower performance compared to natural gas due to the lower heating value of LFG. 


\subsection{SINGLE CELL TESTING ON LANDFILL GAS CONTAMINANTS AND POST TEST ANALYSIS}

Tolerance levels for sulfur and chlorine compounds in landfill gas were established at $100 \mathrm{ppb}$ based on limits established for reforming catalysts and previous bench scale testing with single cell fuel cells. The purpose of the tests conducted in this program was to assess the feasibility of raising the tolerance level to $300 \mathrm{ppb}$, thereby reducing the level to which the LFG clean-up process has to lower these contaminants. A primary concern with chloride contaminants is the potential loss of electrolyte due to the formation of potassium chloride which is more volatile than potassium carbonate, the electrolyte. It was estimated that at $300 \mathrm{ppb}$ chlorides, less than $2 \%$ of beginning of life (BOL) electrolyte will be lost during the life of the power plant, and may be acceptable as shown in Figure 7-1.

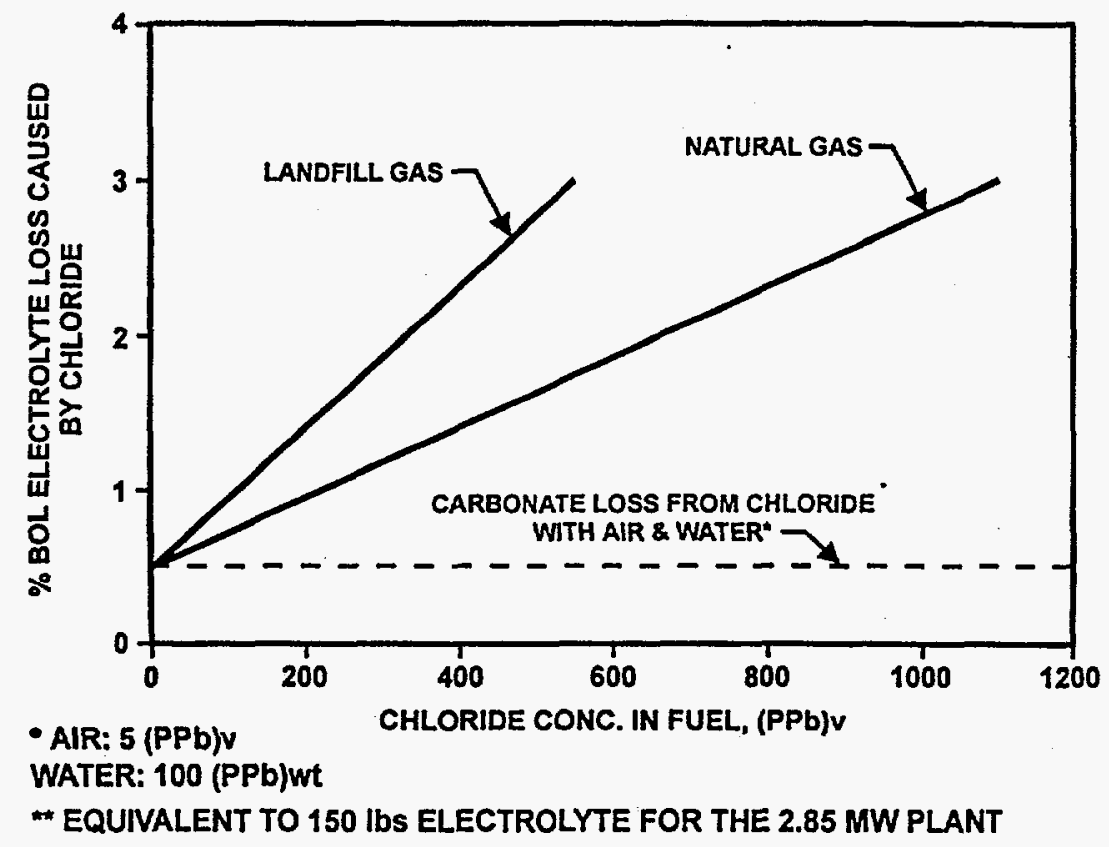

Figure 7-1 CARBONATE ELECTROLYTE LOSS CAUSED BY CHLORIDE IN THE FEED STREAMS:

$<300(\mathrm{ppb})$ Chlorides in Landfill Gas will Limit Electrolyte Loss to $<2 \mathrm{wt} \%{ }^{* *}$ of BOL Inventory

To assess this increase in tolerance level for sulfur and chloride contaminants in LFG, two bench scale single cells $\left(250 \mathrm{~cm}^{2}\right)$ were operated with simulated landfill gas which has been contaminated with these compounds. One cell (Cell No. 7-594) was contaminated with dichlorobenzene to provide an equivalent $300 \mathrm{ppb} \mathrm{Cl}$ in the fuel gas. A second cell (Cell No. 7-605) was contaminated with both dichlorobenzene and hydrogen sulfide. Both cells were assembled using current standard components and cell designs. Prior to operation with LFG contaminant, both cells were tested on standard gases to benchmark performance and were found to have normal initial performance and resistance. Simulated landfill gas and contaminants were introduced to the cells after operating the cells for several hundred hours to stabilize performance. Figure 7-2 shows a typical sub-scale single cell being tested. 


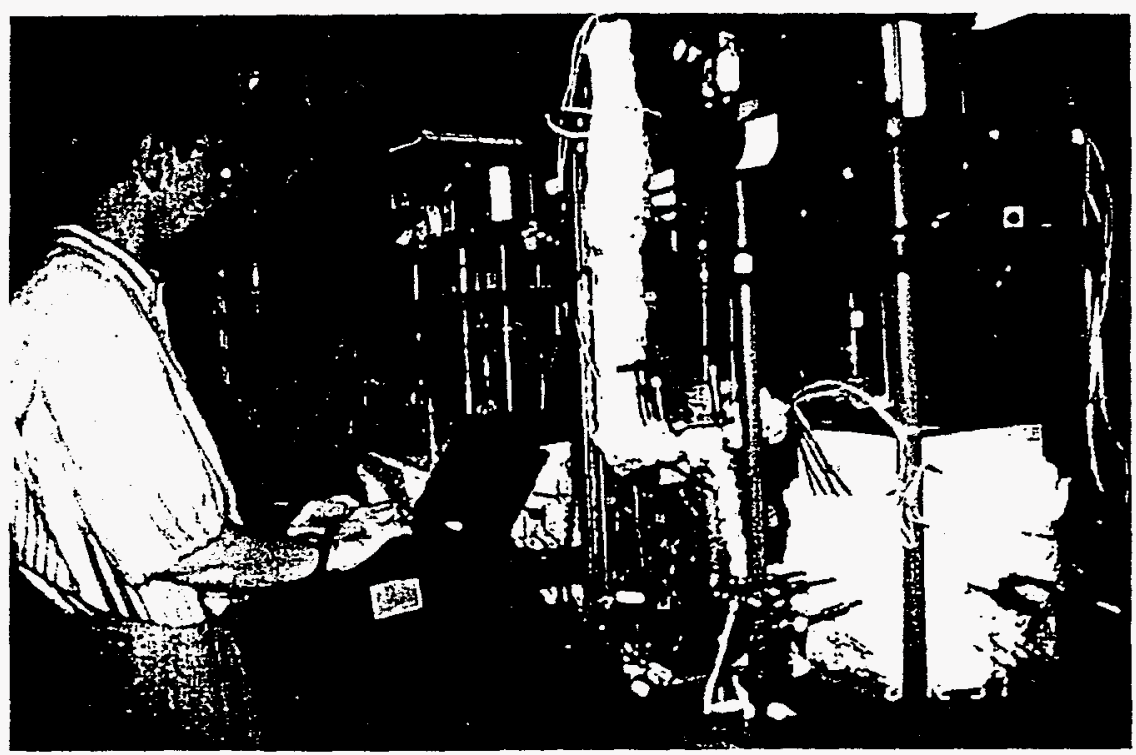

Figure 7-2 SUBSCALE SINGLE CELL TEST FACILITY:

Single cell tests are a convenient vehicle for short $(<4,000 \mathrm{~h})$ duration tests.

The first LFG contaminant test with $300 \mathrm{ppb}$ Chlorides as dichlorobenzene operated approximately 1600 hours. Three hundred hours with standard gases, 200 hours with clean simulated landfill gas and 1100 hours with chloride contaminant in simulated LFG as shown in Figure 7-3. Originally planned to operate for 2000 hours, this test was terminated early due to carbon formation. This was due to low moisture content in the fuel gas and was corrected in the second test. Performance as measured by cell voltage and resistance shown in Figure 7-3 indicates relatively stable operation with the beginnings of a decline in the last two hundred hours of operation.

The second LFG contaminant test, operated with both $300 \mathrm{ppb} \mathrm{Cl}$ as dichlorobenzene and $300 \mathrm{ppb} \mathrm{H}_{2} \mathrm{~S}$ operated for approximately 3000 hours. Seven hundred hours on standard gases, 200 hours with clean simulated LFG, and 2100 hours with chloride and sulfur contaminant in simulated LFG as shown in Figure 7-4. Performance of this cell began to decline after about 1500 hours of operation similar to the first contaminant cell described above. Comparing the performance of these cells to other cells tested without contaminants, indicates that the performance obtained with the 300 $\mathrm{ppb} \mathrm{Cl}$ and $\mathrm{H}_{2} \mathrm{~S}$ contaminants falls within the scatter of standard cell performance tests conducted in the past. It is therefore difficult to conclude conclusively that the $300 \mathrm{ppb}$ level of contaminants tested will lead to excessive performance decay without further testing to establish a statistical data base. 


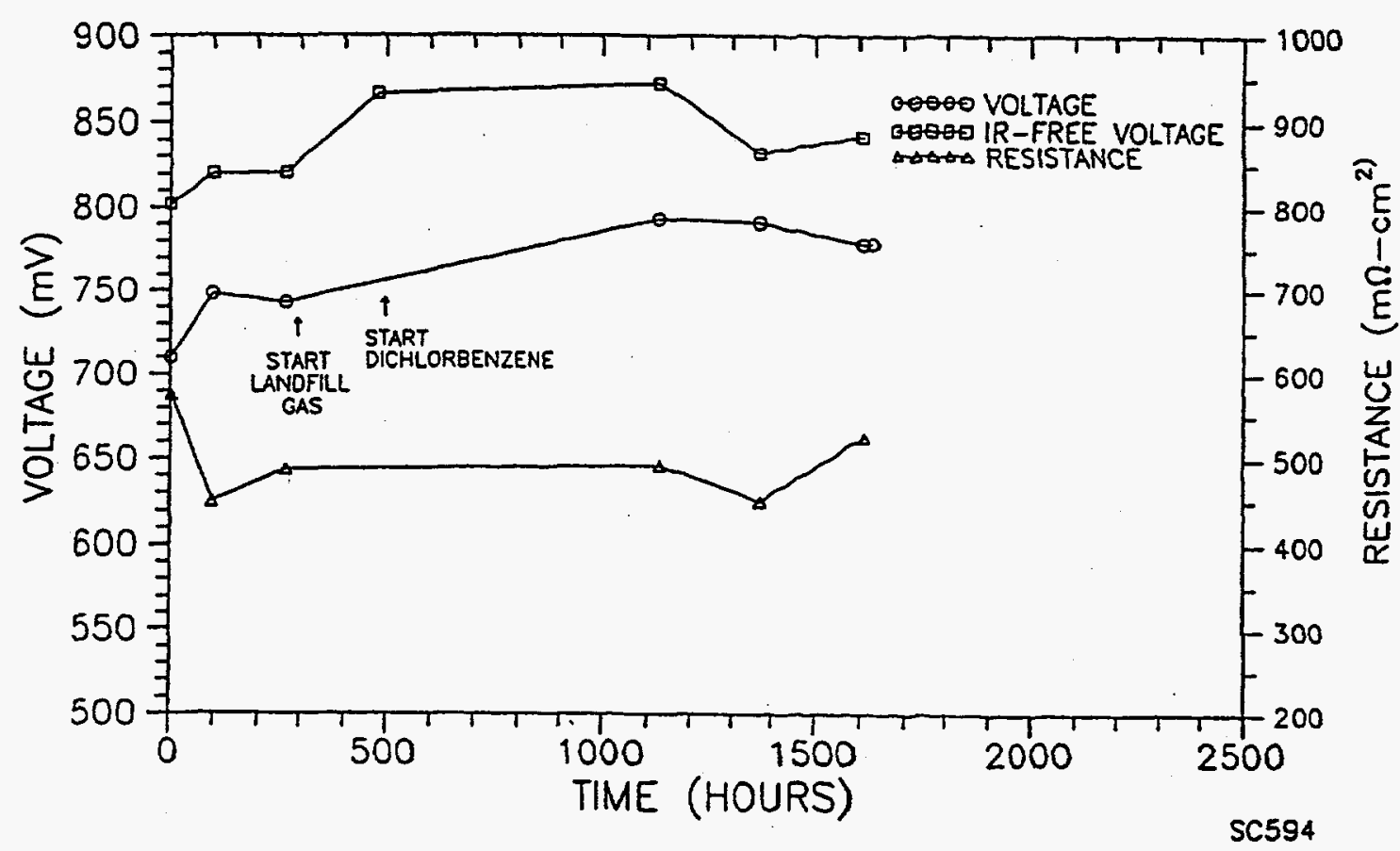

Figure 7-3 SINGLE CELL TEST ON SIMULATED LFG WITH 300 ppb CHLORIDE CONTAMINANT:

Performance began to decline in the last 200 hours.



Figure 7-4 SINGLE CELL TEST ON SIMULATED LFG WITH 300 ppb CI AND 300 ppb S CONTAMINANT:

Performance decline begins at about 1500 hours. 
After completion of testing of the two single cells tested, the cells were disassembled for post test analysis to determine chlorine and sulfur pickup. The anode, cathode and matrix samples were collected from fuel inlet and fuel exit areas of the cell. The anode and cathode current collectors were also analyzed by metallography to determine the effects of contaminants on corrosion. In addition, internal reforming catalyst was also sampled. The electrolyte was washed first using ultra-pure water and analyzed for sulfur, chlorine, Li and $\mathrm{K}$ by Neutron Activation, IR, and AA. The solid residue was then completely digested for similar analysis. For control purposes, samples from a standard cell (\#7-588) which had no contaminant addition, were also collected as a baseline.

Results of the post test analysis showed that there was no detectable pickup of chlorine or sulfur by the anode, cathode, and matrix in cells 7-594 and 7-605, the two contaminant cells tested as compared to the baseline cell 7-588. There was also no detectable chlorine pickup by the reforming catalyst in both cells. However, the catalyst in 7-605, the cell tested with both $\mathrm{Cl}$ and $\mathrm{H}_{2} \mathrm{~S}$ appears to have picked up some sulfur (400$500 \mathrm{ppm}$ compared to $100-130 \mathrm{ppm}$ in regular cells) due to the introduction of $\mathrm{H}_{2} \mathrm{~S}$.

The results of metallography analysis of the anode and cathode current collectors at fuel inlet and outlet indicated no accelerated corrosion of the current collectors for both cells tested as shown in Figure 7-5. However, longer term testing is needed to verify this observation.

The electrolyte inventory in the active cell components of the two cells was analyzed to determine the effect of the contaminants tested on electrolyte loss. The chlorine contaminants may accelerate electrolyte loss by accelerated corrosion or $\mathrm{KCl}$ evaporation. However, analysis of the electrolyte inventory revealed that the electrolyte loss in the contaminant cells tested was similar to other cells tested without contaminants. A mass balance calculation showed that the total amount of chlorine contaminant introduced at the $300 \mathrm{ppb}$ level would not contribute to significant electrolyte loss by evaporation. The corrosion results also point to normal electrolyte loss due to the observed normal corrosion attack.

In summary, the landfill gas contaminant cell tests 7-594 and 7-605 did not reveal increased $\mathrm{Cl}$ or $\mathrm{S}$ pickup compared to other cells tested without contaminants, except for the reforming catalyst in cell 7-605 (tested with $\mathrm{Cl}$ and $\mathrm{H}_{2} \mathrm{~S}$ contaminants). Neither accelerated corrosion nor electrolyte loss were observed beyond the expected level for typical cells.

While these results are encouraging in terms of allowing higher tolerance levels for future operation of carbonate fuel cells on LFG with $\mathrm{Cl}$ and $\mathrm{H}_{2} \mathrm{~S}$ contaminants at $300 \mathrm{ppb}$, additional long term tests are required to confirm these results and to establish a broader statistical data base. The effect of sulfur on the internal reforming catalyst will likely be mitigated by the fact that a pre-reformer is normally part of the power plant system, and this will provide a guard bed to the fuel cell. This reactor may need more frequent replacement as it gradually picks up sulfur. 


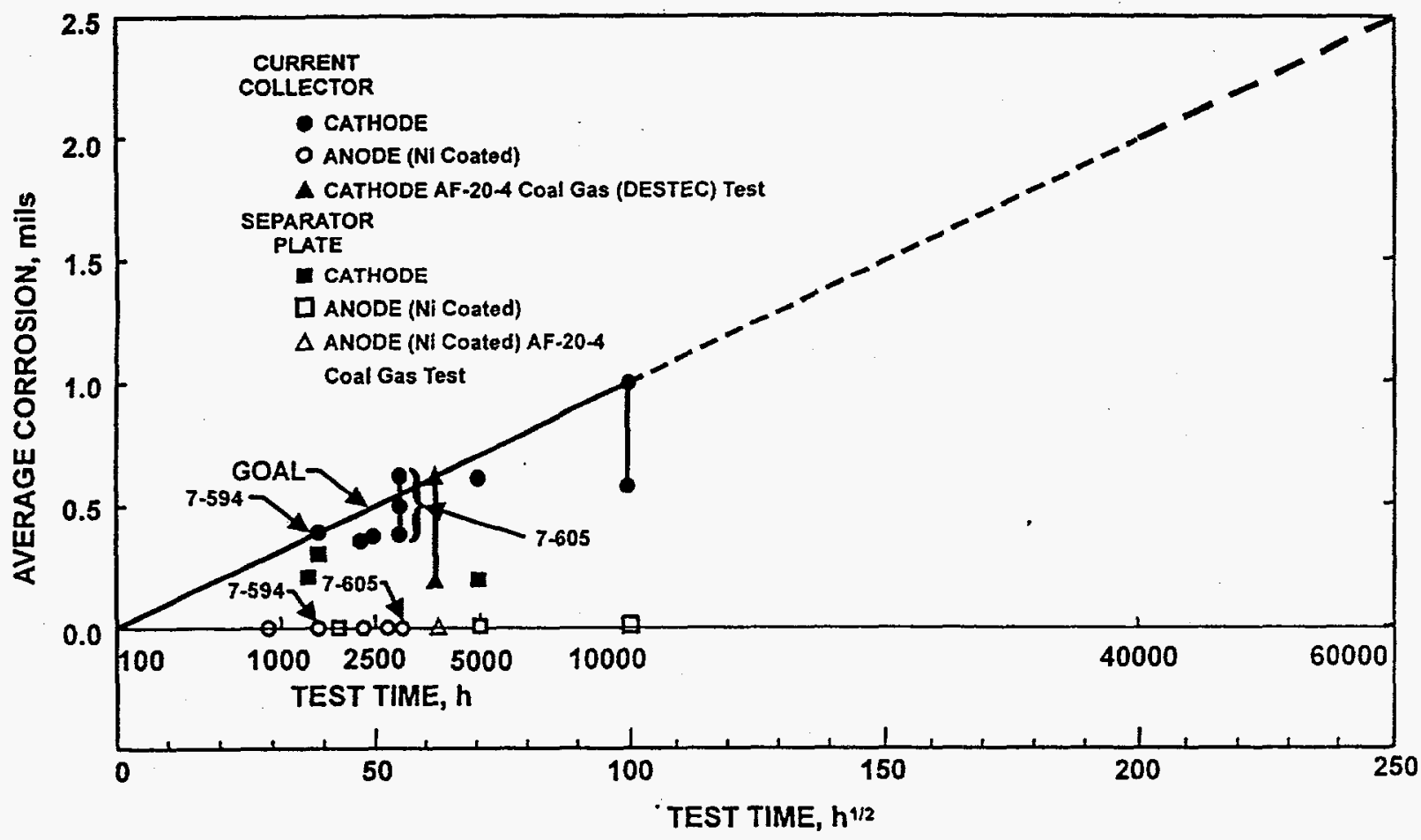

Figure 7.5 POST TEST CORROSION DATA:

Normal corrosion of anode and cathode current collectors observed in the cell components tested. 


\section{DESIGN AND ECONOMIC ANALYSIS OF FULL SCALE GAS CLEANUP SYSTEM}

\subsection{TYPICAL LANDFILL GAS COLLECTION SYSTEM}

Landfills are typically required by the U.S. EPA to install and operate landfill gas collection systems. Many landfill operators have installed and are operating these collection systems. The design of these components is summarized by the U.S. EPA ${ }^{1}$. A typical landfill gas collection system consists of three major components:

1. The gas collection wells

2. Piping that connects to the well heads and brings the gas to a single location for utilization or disposal

3. Centralized gas processing including: dropout pots for removing aqueous condensate, blowers for moving gas and apparatus for final disposition.

In general, the costs of installing a landfill gas collection system can be assigned to the life cycle costs of the landfill operation since installation of a collection system is generally a necessary part of operating the landfill. The design and estimated costs of the collection system are tabulated here for illustrative purposes only. They will provide an order-of-magnitude estimate of the cost of delivering the gas to the gas cleanup/carbonate fuel cell facility.

\subsection{PROTOTYPE GAS CLEANUP SYSTEM DESIGN GUIDE}

\subsubsection{Overall Design}

Based on the results of sub-scale gas cleanup system testing described in Section 5 , a stand-alone landfill gas cleanup system was designed sized for a nominal $3 \mathrm{MW}$ fuel cell power plant. The system includes a compressor and after cooler, bulk sulfur removal, fired heater, hydrogenation, chloride removal, and trace sulfur removal. A fraction of the cleaned fuel is steam reformed and shifted to a hydrogen rich stream which is mixed with the raw landfill gas to provide the hydrogen for the hydrogenation reactions. The composition of the typical raw landfill gas and the gas leaving the cleanup system is shown in Table 8-1. The overall landfill gas cleanup conversion efficiency based on the lower heating value of the landfill gas entering and leaving the system is $93 \%$. The lower heating value of the gas leaving the landfill cleanup system is $442 \mathrm{Btu} / \mathrm{scf}$. The license to this

\footnotetext{
1

"Air Emissions from Municipal Solid Waste Landfills - Background Information for Proposed Standards and Guidelines" U.S. Environmental Protection Agency. NTIS PB91-197061. March 1991.
} 
Table 8.1 LANDFILL GAS COMPOSITION BEFORE AND AFTER CLEANUP: Design basis for 3MW LFG cleanup system.

\begin{tabular}{|l|c|c|}
\hline CONSTITUENT & $\begin{array}{c}\text { RAW LANDFILL } \\
\text { GAS, \% vol }\end{array}$ & $\begin{array}{c}\text { CLEANED LANDFILL } \\
\text { GAS, \% vol }\end{array}$ \\
\hline Hydrogen & 0.1 & 7.7 \\
Methane & 48.1 & 41.9 \\
Carbon Dioxide & 35.2 & 34.5 \\
Carbon Monoxide & 0.0 & 0.0 \\
Water Vapor & 1.4 & 2.6 \\
Nitrogen & 14.5 & 13.3 \\
Oxygen & 0.0 & 0.0 \\
Sulfur & $50,000 \mathrm{ppbv}$ & $<100 \mathrm{ppbv}$ \\
Chlorine & $9,000 \mathrm{ppbv}$ & $<100 \mathrm{ppbv}$ \\
\hline
\end{tabular}

(LFG) clean-up technology is held by the Electric Power Research Institute (EPRI), and is described in greater detail in EPRI Technical Report TR-108043. ${ }^{1}$ A summary of the cleanup system follows.

Landfill gas (LFG) enters the system at near atmospheric pressure from the landfill and is mixed with a hydrogen-rich recycle stream. The LFG is then compressed to 46 psia $\left(3.2 \mathrm{bar}\right.$ ) and cooled to $140^{\circ} \mathrm{F}\left(60^{\circ} \mathrm{C}\right)$. The cooled stream flows to the bulk sulfur removal where the hydrogen sulfide concentration is lowered to a level of about $1,000 \mathrm{ppbv}$ on average.

The gas leaving the bulk sulfur removal stage is indirectly heated by burning a small amount of the gas leaving the bulk sulfur removal unit in a fired heater. The gas then flows to the hydrogenation unit. In the hydrogenation unit, trace organic sulfur compounds are converted to $\mathrm{H}_{2} \mathrm{~S}$ and chlorinated hydrocarbons are converted to $\mathrm{HCl}$. Oxygen is also consumed in this unit by combustion with hydrogen. The hydrotreated stream then flows through the chloride and trace sulfur removal solids. At this point, the landfill gas leaves the system with the composition shown in Table 8-1.

As previously mentioned, a portion of the clean fuel is mixed with steam and flows to a thermal steam reformer where the fuel is converted to hydrogen and $\mathrm{CO}$. Heat for the steam reforming reaction is provided by burning a small amount of the gas leaving the bulk sulfur removal unit. The stream leaving the reformer is then cooled and flows to a shift converter where the $\mathrm{CO}$ and remaining steam are reacted producing a hydrogen-rich gas with $52 \%$ hydrogen and only about $2 \% \mathrm{CO}$. This gas is then dried and mixed with the raw landfill gas at the inlet of the compressor to provide hydrogen needed for the hydrogenation reactions.

${ }^{1}$ Interested parties can contact EPRI (3412 Hillview Avenue, P.O. Box 10412, Palo Alto, CA 94303, Tel: $415-855-2000$ ). 
For economic evaluation, the full scale landfill gas cleanup system is designed as a stand-alone system (i.e. not integrated with the fuel cell power plant) and sized to provide about 1 MMscfd (1 million standard cubic feet per day; $28,300 \mathrm{Nm}^{3} /$ day) of fuel to a direct carbonate fuel cell power plant. The landfill gas cleanup system requires about $77 \mathrm{~kW}$ of power for the gas compressor, burner air blowers, cooling fans, boiler feed pump and controller. The fuel cell power plant delivers $2.77 \mathrm{MW}$ AC power at an LHV efficiency of $50 \%$. If the landfill gas cleanup system is thermally integrated with the fuel cell system, with waste heat from the fuel cell stack exhaust providing the heat for raising the fuel to hydrotreating temperature (rather than burning fuel in the burner), the overall system efficiency is improved to $52.2 \%$. The fuel cell system operating on clean LFG is shown in the Appendix.

The overall cleanup system is packaged on a skid that is 10 feet $(3.0 \mathrm{~m})$ wide by 12 feet $(3.7 \mathrm{~m})$ high and 22 feet $(6.7 \mathrm{~m})$ long, and is expected to weigh about $60,000 \mathrm{lbs}$ $(27,200 \mathrm{~kg})$, as shown in Figure $8-1$. The design is based on factory assembly, truck transport to the site and outdoor operation. The two bulk sulfur removal vessels are located at one end of the skid, and the hydrogenation bed and zinc oxide bed are located at the other end of the skid. Other equipment, including the reformer, shift converter, condenser, cooler, the compressor and heater, are located in the center region of the skid between the four process vessels.
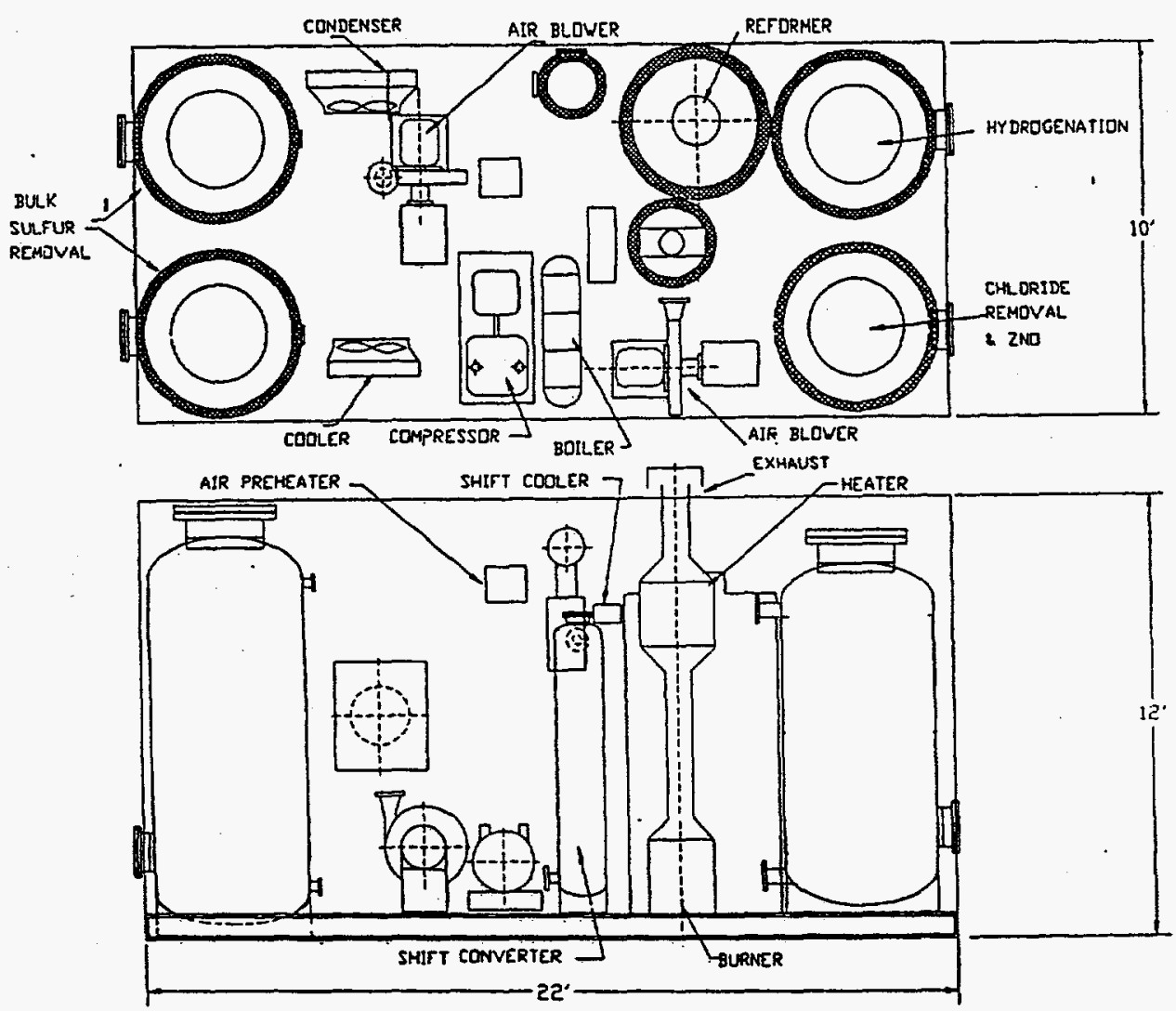

RAS $3 / 23 / 97$

Figure 8-1 3MW LFG CLEANUP SYSTEM PRELIMINARY EQUIPMENT LAYOUT:

Equipment can fit on a skid $22^{\prime} \times 10^{\prime}$. 


\subsubsection{Bulk Sulfur Removal}

The bulk sulfur removal is designed to remove $53,000 \mathrm{ppbv}$ of $\mathrm{H}_{2} \mathrm{~S}$ in the raw landfill gas down to an average 1,000 ppbv. Supported iron oxide is used for this step as provided by SulfaTreat. SulfaTreat, manufactured by the SulfaTreat Company (Chesterfield, Missouri), is a mixture of ferric oxide and tri-ferric oxide supported on an inert inorganic substrate. The advantages of SulfaTreat are its low cost, its low operating temperature $\left(140^{\circ} \mathrm{F}, 60^{\circ} \mathrm{C}\right)$, and its ability to reduce the hydrogen sulfide level to $1,000 \mathrm{ppbv}$. In addition, it is non-hazardous and can be used on site as fill material, road base, or as a soil amendment, eliminating disposal costs.

Two beds are used in a lead/lag configuration. When the second bed breaks through at $5,000 \mathrm{ppbv}_{2} \mathrm{~S}_{1}$ it is placed as a leading bed, while a fresh bed is placed in the lagging position. Switching is done by appropriate use of valves. A saturated sulfur loading of $10.5 \%$ is used, consistent with loadings measured during the Anoka testing and conservative recommendations from a SulfaTreat supplier. The lead vessel is changed after 151 days of operation or about $51 / 2$ months. Table $8-2$ contains the design basis for the bulk sulfur removal stage.

Table 8-2 DESIGN BASIS FOR BULK HYDROGEN SULFIDE REMOVAL USING SULFA TREAT

Two vessels with $6000 \mathrm{lbs}$ SulfaTreat sorbent in each are required.

\begin{tabular}{|c|c|}
\hline $\begin{array}{l}\text { INLET CONDITIONS } \\
\text { Pressure } \\
\text { Temperature } \\
\text { Flow } \\
\text { Water Content } \\
\mathrm{CO}_{2} \text { Content } \\
\mathrm{O}_{2} \text { Content } \\
\mathrm{H}_{2} \mathrm{~S} \text { Content }\end{array}$ & $\begin{array}{c}45 \text { psig ( } 3.1 \text { bar, gauge) } \\
140 \mathrm{~F}(60 \mathrm{C}) \\
\left.1,100 \text { MMSCFD ( } 31,150 \mathrm{Nm}^{3} / \text { day }\right) \\
\text { saturated } \\
40 \text { mol\% } \\
0.5 \text { mol\%, max } \\
45,000 \text { ppbv }\end{array}$ \\
\hline $\begin{array}{l}\text { STAGE DESIGN } \\
\text { Number of vessels } \\
\text { Inside diameter } \\
\text { Bed height (each vessel) } \\
\text { SulfaTreat Inventory (each vessel) }\end{array}$ & $\begin{array}{c}2 \text { (piped in series, lead/lag) } \\
48 \text { inches }(1.22 \mathrm{~m}) \\
6.8 \mathrm{ft}(2.1 \mathrm{~m}) \\
6000 \mathrm{lb}(2,720 \mathrm{~kg})\end{array}$ \\
\hline $\begin{array}{l}\text { PREDICTED RESULTS AFTER } \\
\text { FIRST CHANGEOUT } \\
\text { Outlet } \mathrm{H}_{2} \mathrm{~S} \text { concentration (at } \\
\text { changeout) } \\
\text { Total Pressure Drop ( } 2 \text { vessels) } \\
\text { Days to change lead vessel } \\
\mathrm{H}_{2} \mathrm{~S} \text { removed (each vessel) }\end{array}$ & $\begin{array}{c}5,000 \text { ppbv } \\
1.6 \text { psig (0.11 bar, gauge) } \\
151 \\
634\end{array}$ \\
\hline
\end{tabular}




\subsubsection{Trace Sulfur Removal}

The bulk sulfur removal stage is followed by a trace sulfur removal stage. This consists of a hydrogenation unit which hydrogenates the organic sulfur compounds to form $\mathrm{H}_{2} \mathrm{~S}$ by reaction with hydrogen. The hydrogen required is provided by a recycle stream which reforms and shifts about $9 \%$ of the clean landfill gas. The $\mathrm{H}_{2} \mathrm{~S}$ produced is removed by a zinc oxide sorbent which removes the $\mathrm{H}_{2} \mathrm{~S}$ according to the following reaction:

$$
\mathrm{ZnO}+\mathrm{H}_{2} \mathrm{~S} \leftrightarrow \mathrm{ZnS}+\mathrm{H}_{2} \mathrm{O}
$$

This reaction lowers the concentration of $\mathrm{H}_{2} \mathrm{~S}$ to below $50 \mathrm{ppb}$ as shown in Figure 8-2. Low $\mathrm{H}_{2} \mathrm{~S}$ concentration is favored by low water content and by lower temperatures. However, even at a relatively high water content of $3 \%$, the maximum $\mathrm{H}_{2} \mathrm{~S}$ is below $45 \mathrm{ppb}$ which is acceptable compared to the $<100 \mathrm{ppb}$ goal.

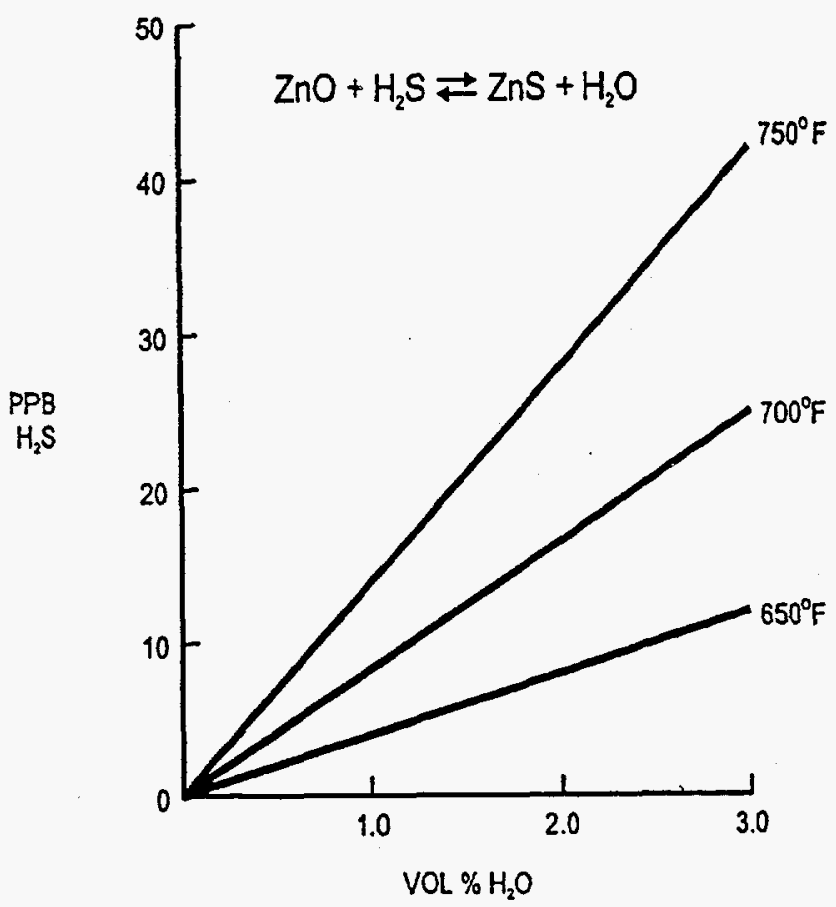

Figure 8-2 HYDROGEN SULFIDE EQUILIBRIUM OVER ZINC OXIDE:

$\mathrm{H}_{2} \mathrm{~S}$ at equilibrium with $\mathrm{ZnO}$ is less than $25 \mathrm{ppbv}$ at $3 \%$ moisture and $700^{\circ} \mathrm{F}$.

The zinc oxide is located in the lower portion of a $4 \mathrm{ft}$ diameter vessel which is shared with the chloride guard. Replacement of the zinc oxide will be required every two years.

\subsubsection{Chlorinated Hydrocarbon Removal}

No activated carbon beds are included in the revised prototype system design for chlorinated hydrocarbon removal. Chlorine is removed by first converting to hydrogen 
LANDFILl gas Cleanup For CARbonate

FUEL CELL POWER GENERATION

chloride at high temperature and then removing the hydrogen chloride by reaction with potassium carbonate or calcium oxide promoted activated alumina at high temperature.

The total chlorinated hydrocarbons at the Anoka site were measured at $4,500 \mathrm{ppbv}$. These include the following:

$\begin{array}{lr}\text { Vinyl Chloride } & 1200 \mathrm{ppbv} \\ \text { Dichlorobenzenes } & 1500 \mathrm{ppbv} \\ \text { Trichloroethylene } & 700 \mathrm{ppbv} \\ \text { Tetrachloroethylene } & 480 \mathrm{ppbv} \\ \text { Methylene chloride } & 350 \mathrm{ppbv} \\ \text { Trichlorofluoromethane } & 100 \mathrm{ppbv} \\ \text { Trichlorethanes } & 40 \mathrm{ppbv} \\ & \\ \text { Total halogenated hydrocarbons } & 4,500 \mathrm{ppbv}\end{array}$

Note that several of these compounds contain more than one chlorine atom. The resulting equivalent chlorine concentration (for one chlorine per molecule) is 9,000 ppbv. The landfill gas cleanup system is designed to convert the chlorine in chlorinated hydrocarbons to $\mathrm{HCl}$ by reaction with hydrogen gas. The $\mathrm{HCl}$ is subsequently removed by a chloride guard sorbent. The material tested at Anoka was a potassium carbonate based sorbent. Analysis of the equilibrium $\mathrm{HCl}$ expected for the reaction below indicates that relatively high levels of $\mathrm{HCl}$ are achieved at the conditions present in the LFG cleanup process as shown in Figure 8-3 if only reaction with potassium carbonate occurs.

$$
2 \mathrm{HCl}+\mathrm{K}_{2} \mathrm{CO}_{3} \neq 2 \mathrm{KCl}+\mathrm{CO}_{2}+\mathrm{H}_{2} \mathrm{O}
$$

The high level of $\mathrm{CO}_{2}$ in the landfill gas inhibits the reduction of $\mathrm{HCl}$ concentrations to the sub ppm level. However, in addition to reaction with potassium carbonate, $\mathrm{HCl}$ is also removed by chemisorption on the alumina support used for the chlorine guard. It is surmised that this allows the chloride level to be reduced further. Testing at Anoka indicated that the $\mathrm{HCl}$ downstream of the chloride guard is less than $300 \mathrm{ppbv}$.

Other materials are also available such as calcium promoted chloride guards which are capable of reducing the $\mathrm{HCl}$ concentration to less than $100 \mathrm{ppbv}$ in the presence of carbon dioxide. The choice of chloride guard may be dictated by the level of chlorides to be removed, and the economics of site specific cases.

\subsection{COST ESTIMATES}

\subsubsection{Gas Collection System Capital Costs}

The costs of installing and operating a landfill gas collection system are typically a part of the life cycle costs of the landfill operation. Such systems are typically required by environmental regulations to collect the landfill gas and flare it prior to release to the atmosphere. Thus, the gas collection system costs will not, generally, be a part of power 


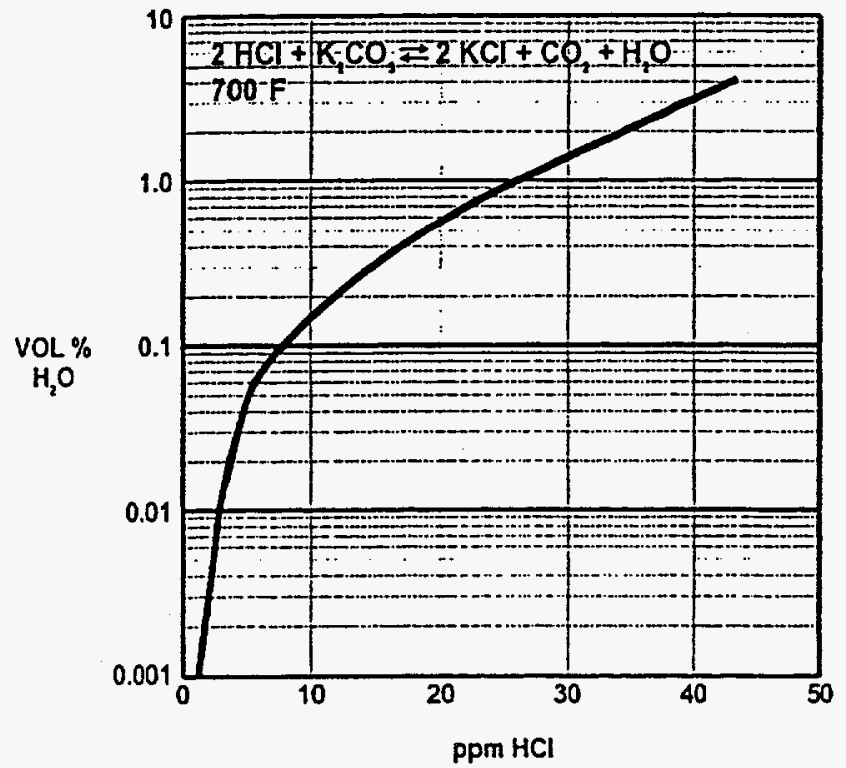

Figure 8-3 HYDROGEN CHLORIDE EQUILIBRIUM OVER POTASSIUM CARBONATE:

$\mathrm{CO}_{2}$ in the landfill gas inhibits removal of $\mathrm{HCl}$ to very low levels by reaction with $\mathrm{K}_{2} \mathrm{CO}_{3}$.

generation system costs. Collection system costs are included here to provide an order of magnitude estimate for delivery of the raw gas to the gas cleanup system.

The U.S. EPA has published a tool for estimating the costs of collecting landfill gas ${ }^{1}$. This detailed cost estimating tool was simplified under a reasonable set of assumptions. The assumptions and the simplified tools are described below. The simplified tools were developed under the following procedures (using guidelines recommended by U.S. EPA):

- Costs were escalated to November 1996 dollars using specific Chemical Engineering Magazine equipment cost indices.

- Direct costs include acquisition of hardware, labor, taxes, shipping, and installation.

- Indirect costs are estimated to be $37 \%$ of direct costs and include engineering, supervision, field expenses, fees, start-up, testing, and contingencies. These costs are included in the simplified estimates given below.

“Air Emissions from Municipal Solid Waste Landfills - Background Information for Proposed Standards and Guidelines" U.S. Environmental Protection Agency. NTIS PB91-197061. March 1991. 
Not included are costs associated with flare systems to incinerate the gas. The requirements for such a system will depend on the details of the overall design, but it is likely that a flare system will be required to dispose of gas during periods when the carbonate fuel cell system cannot accept gas.

\section{Landfill Gas Collection Wells}

Wells are constructed throughout the landfill to accumulate the gas produced. The wells are constructed short of the actual depth of the landfill to avoid disturbing leachate collection systems at the bottom of the landfill. A well depth of $75 \%$ of the landfill depth was assumed here. A gas collection rate of 0.12 cubic meters per minute for each meter of landfill depth at the well location was recommended and was used here. The simplified cost estimate for construction of collection wells is:

$$
C_{w}=\frac{Q_{T}}{243}
$$

where: $\quad \mathrm{C}_{\mathrm{w}} \quad=$ cost of constructing wells, dollars

$$
Q_{T} \quad=\text { total gas flow, } \mathrm{m}^{3} / \mathrm{yr}
$$

\section{Inter-connecting Piping}

This category includes the costs of connecting the well head to the header piping and the header piping to route the gas to a central collection point. These costs are proportional to the number of wells which depends on the average depth of the landfill. It was assumed that the header piping associated with each well is the average well-towell spacing distance. It was also assumed that the landfill gas production rate was 180 cubic meters of gas per year for every cubic meter of landfill solids. The simplified cost estimate for inter-connecting piping is:

$$
C_{p}=\frac{Q_{T}}{15 H}
$$

where: $\quad \mathrm{C}_{\mathrm{p}} \quad=$ cost of inter-connecting piping, dollars

$Q_{T} \quad=$ total gas flow, $\mathrm{m}^{3} / \mathrm{yr}$

$\mathrm{H} \quad$ = depth of the landfill, $\mathrm{m}$

\section{Condensate Collection/Blower}

As the landfill gas moves from the warm interior of the landfill to the cooler surface, water vapor will condense on the cooler pipe walls. Trace contaminants in the gas may also collect in the condensate. This condensate must be separated and treated $\mathrm{pH}$ 
adjustment) before being discharged to a wastewater treatment works. The costs accumulated here are for separation of the condensate, $\mathrm{pH}$ adjustment, and liquid piping. Aqueous disposal costs are operating costs. Gas is moved through the collection system wells and piping by means of blowers powered by electric motors. (No blower redundancy was included in the cost estimates shown below.) The simplified cost estimates for the condensate collection and gas blowers combined is:

$$
C_{c}=3.78 Q_{T}^{0.6}
$$

where: $\quad \mathrm{C}_{\mathrm{c}} \quad=$ cost of condensate knock-out and gas blowers, dollars

$$
Q_{T} \quad=\text { total gas flow, } \mathrm{m}^{3} / \mathrm{yr}
$$

\subsubsection{Gas Collection System Operating Costs}

The yearly cost of operating a landfill gas collection system includes labor, material, electricity (for the gas blowers), condensate disposal, property ownership, property taxes, insurance, and administration. The U.S. EPA estimates these yearly costs to be $50 \%$ of the capital cost.

\subsubsection{Gas Collection System Cost Summary}

The simplified tools described above are applied to a hypothetical landfill which generates 10.3 million cubic meters of gas per year (1 MMSCFD)and has an average depth of 30 meters. Note that this hypothetical landfill is very small. These parameters were selected to match the gas inflow to the carbonate fuel cell plant described below to illustrate the comparative costs.

\subsubsection{Gas Cleaning System Capital Costs}

The capital cost of the packaged landfill cleanup system capable of delivering 1 MMSCFD $\left(28,300 \mathrm{Nm}^{3} /\right.$ day $)$ is based on low volume production and estimated in first quarter 1997 dollars. Costs of the various catalysts and sorbents were provided by their suppliers. The pressure vessel, piping and thermal insulation cost was established using procedures from Richardson'. Heat exchanger cost is based on weight of the heat exchangers as established by design sizing and cost estimated using the cost per weight

"Process Plant Construction Estimating Standards" published by Richardson Engineering Services, Inc. Mesa, AZ 


\begin{tabular}{|l|c|c|}
\hline \multicolumn{1}{|c|}{ Cost Component } & Capital Cost Calculation & Capital Cost \\
\hline Collection Wells & $C_{w}=\frac{Q_{T}}{243}$ & \\
& & \\
\hline Piping & $C_{p}=\frac{Q_{T}}{15 H}$ & \\
& & \\
& & \\
\hline Condensate Collection/Blower & $C_{c}=3.78 Q_{T}^{0.6}$ & \\
& & \\
\hline & & \\
\hline Total Capital Costs & & \\
\hline
\end{tabular}

based on recent vendor quotations on heat exchangers of the same general type and size. Control valve and instrument costs are based on recent vendor quotations for items in the same category. The overall capital cost is estimated to be $\$ 1.177$ million.

\subsubsection{Gas Cleaning System Operating Costs}

The primary operating cost is expected to be the cost for periodic replacement of the catalysts and sorbents. Table 8-3 lists, for each process bed, yearly cost for each of the catalysts and sorbents. Also indicated is the yearly labor cost associated with each bed change-out.

\subsubsection{Gas Collection/Cleaning System Overall Cost Summary and Cost Sensitivities}

A summary of the capital and operating costs for the 1 MMSCFD (10.3 million $\mathrm{Nm}^{3} / \mathrm{yr}$ ) gas collection/cleaning system is given in Table 8-4. These costs were based on contaminant levels measured at the Anoka landfill; 40,000 ppbv $\mathrm{H}_{2} \mathrm{~S}, 7,000$ ppbv organic sulfur and 9,000 ppbv equivalent chlorine. The cleanup cost is about \$1.04/MMBTU which is equivalent to $\$ 459 / \mathrm{MMSCF}$ based on the lower heating value of the gas at the Anoka landfill of about $441 \mathrm{BTU} / \mathrm{SCF}$. This baseline cost also includes a utility cost for the gas compressor of $\$ 0.04 / \mathrm{kWh}$. 
Table 8-3 LANDFILL GAS CLEANUP SYSTEM SORBENT AND CATALYST COSTS:

Annual operating cost for sorbents and catalysts is $\$ 21,900$.

\begin{tabular}{|c|c|c|c|}
\hline MATERIAL & CATEGORY & $\begin{array}{l}\text { REPLACEMENT } \\
\text { INTERVAL }\end{array}$ & $\begin{array}{l}\text { ANNUAL } \\
\text { COST }\end{array}$ \\
\hline SulfaTreat & $\begin{array}{l}\text { Material } \\
\text { Labor }\end{array}$ & 9 months & $\begin{array}{r}\$ 2,272 \\
2,560\end{array}$ \\
\hline Hydrogenation Catalyst & $\begin{array}{l}\text { Material } \\
\text { Labor }\end{array}$ & 60 months & $\begin{array}{r}\$ 1,960 \\
384\end{array}$ \\
\hline Chlorine Guard & $\begin{array}{l}\text { Material } \\
\text { Labor }\end{array}$ & 24 months & $\begin{array}{r}\$ 2,250 \\
960\end{array}$ \\
\hline Zinc Oxide & $\begin{array}{l}\text { Material } \\
\text { Labor }\end{array}$ & 24 months & $\begin{array}{r}\$ 3,600 \\
2,160\end{array}$ \\
\hline Reformer Catalyst & $\begin{array}{l}\text { Material } \\
\text { Labor }\end{array}$ & 24 months & $\begin{array}{r}\$ 3,600 \\
2,160\end{array}$ \\
\hline Shift Catalyst & $\begin{array}{l}\text { Material } \\
\text { Labor }\end{array}$ & 60 months & $\begin{array}{l}\$ \quad 560 \\
\quad 384\end{array}$ \\
\hline \multicolumn{3}{|l|}{$\begin{array}{l}\text { Material Total } \\
\text { Labor Total }\end{array}$} & $\$ 14,500$ \\
\hline Overall Total & & & 21,900 \\
\hline
\end{tabular}

Table 8-4 LANDFILL GAS COLLECTION/CLEANUP COST SUMMARY: 1 MMSCFD Gas Flow

The cost to cleanup LFG is $\$ 1.14$ million in capital cost.

\begin{tabular}{|l|c|r|}
\hline \multicolumn{1}{|c|}{ COST CATEGORY } & CAPITAL & YEARLY COST \\
\hline Collection System & $\$ 126,622$ & 12,622 \\
Collection System Operations & & 63,311 \\
& $\$ 1,140,604$ & 114,060 \\
Cleanup System & & 54,649 \\
Cleanup System Operations & & $\$ 244,642$ \\
Yearly Total & & \\
\hline
\end{tabular}


The sensitivity of the landfill gas clean-up cost to various parameters is shown in Figure 8.3 . The relative clean-up cost (compared to the baseline $\$ 1.04 / \mathrm{MMBtu}$ ) is shown as a function of the relative contaminant level for each individual contaminant: $\mathrm{H}_{2} \mathrm{~S}$, organic sulfur and chlorine. In this sensitivity analysis it is assumed that the basic mechanical design remains the same. As the contaminant level is changed the interval between bed replacement is effected with a corresponding effect on the yearly labor and material cost for bed change-out, which in turn effects the clean-up costs. The clean-up cost sensitivity to the utility power cost is also shown.

The cost for landfill gas cleanup can be estimated directly using the following:

$$
\text { Cost }=\frac{320.9+1863 U P C+\frac{0.543}{1,000} H_{2} S+\frac{2.064}{1,000} R S+\frac{1.776}{1,000} \mathrm{HCl}}{L H V}
$$

Where: $\quad$ Cost $=$ Levelized gas cleanup cost, $\$ / M M B t u$

UPC = Utility power cost, $\$ / \mathrm{kWh}$

$\mathrm{H}_{2} \mathrm{~S}=$ Hydrogen sulfide concentration, $\mathrm{ppbv}$

RS = Organic sulfur concentration, ppbv

$\mathrm{HCl}=$ Chlorine concentration, ppbv

LHV = Gas Lower Heating Value, Btu/dscf

These costs include gas clean-up costs only. If collection system costs are to be included, they must be added to the clean-up costs. 


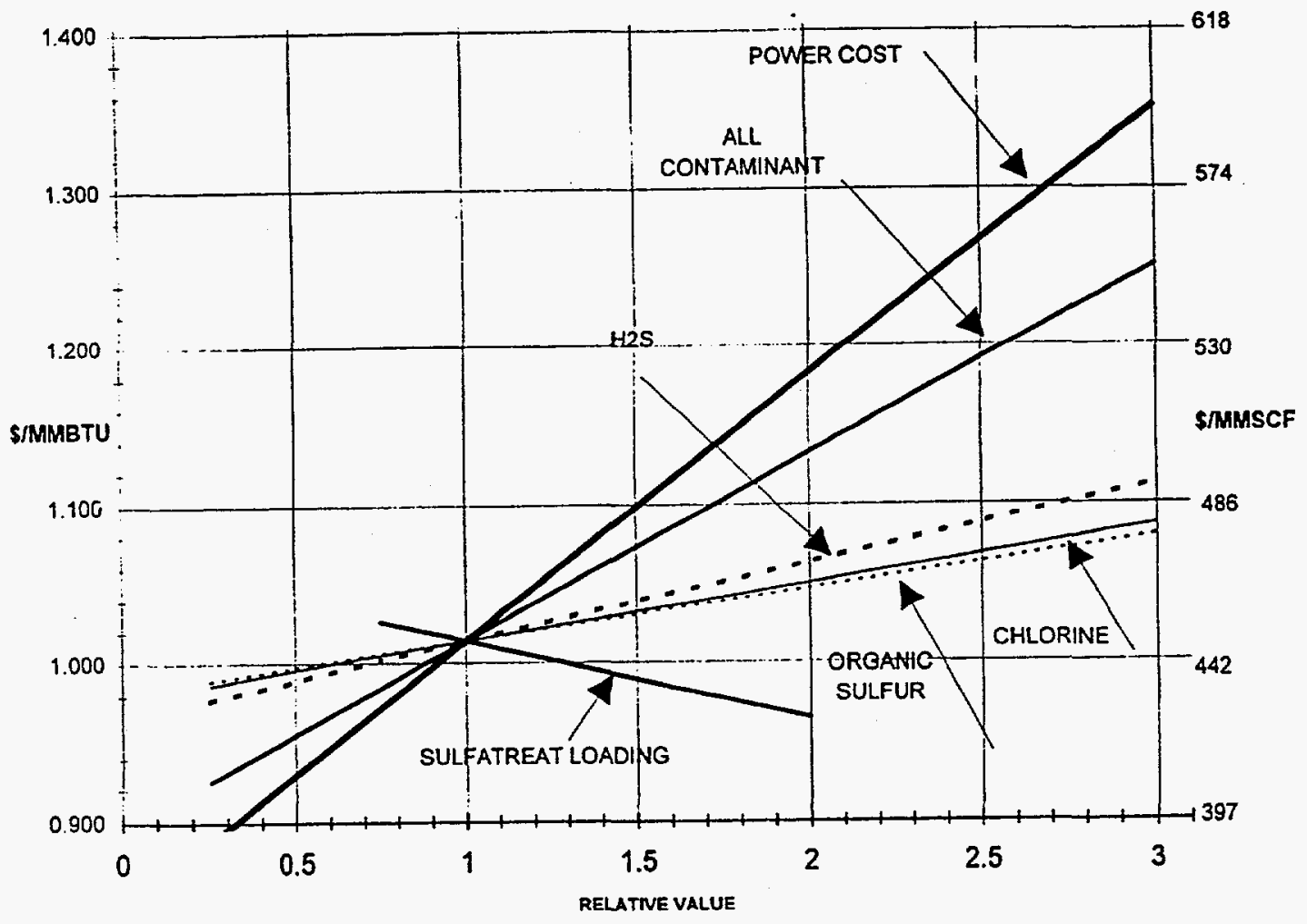

Figure 8-4 LANDFILL GAS CLEAN-UP COST SENSITIVITY

Baseline conditions below are represented by relative parameter of 1 on $x$-axis.

$\begin{array}{lll}\text { Baseline Conditions: } & \text { Gas LHV } & 441 \mathrm{Btu} / \mathrm{scf} \\ & \text { Electric Power } & \$ 0.04 / \mathrm{kW} \\ & \text { Hydrogen Sulfide Concentration } & 40,000 \mathrm{ppbv} \\ & \text { Organic Sulfur Concentration } & 7,000 \mathrm{ppbv} \\ & \text { Chlorine Concentration } & 9,000 \mathrm{ppbv} \\ & \text { Cleanup Cost } & \$ 1.01 / \mathrm{MMBtu}\end{array}$




\section{CONCLUSIONS}

Landfill gas provides a resource for power generation which can be utilized efficiently in carbonate fuel cells. The utilization of landfill gas for power generation using high efficiency power generators will minimize green-house gas emissions from landfills by consuming the methane that would otherwise be released while providing a valueadded product. It is estimated that $6000 \mathrm{MW}$ of power can be generated in the United States by utilizing LFG. This could off-set an equivalent amount of imported gas and/or oil and reduce the net emissions to the environment thereby reducing man-made contributions to global warming. While LFG collection systems and flaring can also reduce the methane emissions from landfills, the energy content of the gas is lost with this approach.

To utilize landfill gas for power generation using carbonate fuel cells, the LFG must be cleanedup to remove sulfur and chlorine compounds. This not only benefits the operation of the fuel cell, but also benefits the environment by preventing the emission of these contaminants to the atmosphere. Commercial technologies for gas processing are generally economical in relatively large sizes (3 MMSCFD or larger), and may not achieve the low levels of contaminants required.

To address the issue of LFG clean-up for fuel cell application, a process was developed utilizing commercially available technology. A pilot-scale test facility utilizing this process was built at a landfill site in Anoka, Minnesota using the EPRI fuel cell test facility used for coal gas testing. The pilot plant was tested for 1000 hours, processing $970,000 \mathrm{SCF}\left(27,500 \mathrm{Nm}^{3}\right)$ of landfill gas. Testing indicated that the process could achieve the following concentrations of contaminants in the clean gas:

- Less than 80 ppbv hydrogen sulfide
$-\quad$ Less than $1 \mathrm{ppm}$ (the detection limit) organic sulfur
$-\quad$ Less than $300 \mathrm{ppbv}$ hydrogen chloride
$-\quad 1.5 \mathrm{ppm}$ (average) Sulfur Dioxide

Most of the analysis of clean landfill gas resulted in contaminant levels below detection limits. In the case of organic sulfur, the detection limit was relatively high compared to the desired goal of $100 \mathrm{ppbv}$. While the clean-up system reduced all contaminants to very low levels, there remains some uncertainty as to the level of total sulfur and total chlorides. The potential for a total sulfur of about $2.5 \mathrm{ppm}$ and total chloride of about 900 ppbv exists due to the detection limits and the cumulative effect of the many (29) chlorinated hydrocarbons which were reduced to $20-80 \mathrm{ppbv}$. Attempts at determining the total chlorides did not result in detection limits below $1 \mathrm{ppm}$. Analysis to very low detection limits (below 100 ppbv) for total sulfur and total chlorides remains to be 
carried out to ascertain that the goals of less than $100 \mathrm{ppbv}$ total sulfur and total chlorides are achieved.

Preliminary design of a $3 \mathrm{MW}$ scale clean-up system was carried out, and a cost estimate made for this clean-up system based on the process tested at Anoka. This system was designed to provide sufficient gas (1 MMSCFD) to power a $2.77 \mathrm{MW}$ carbonate fuel cell. The capital cost for the clean-up system was estimated at $\$ 1,140,600$, which translates to $\$ 1.01 / \mathrm{MMBTU}$ including operating costs and using the Anoka data as a design basis. A sensitivity analysis indicates that the cost of power for compression of the LFG has the largest impact on the cost of clean-up. As the power cost is increased from the baseline $\$ 0.04 / \mathrm{kWh}$ to $\$ 0.12 / \mathrm{kWh}$, the clean-up cost increases to $\$ 1.34 / M M B T U$. As the level of contaminants in the landfill gas varies there is a small impact on the cost of cleanup as well. For a landfill gas which has 3 times the levels of contaminants $\left(\mathrm{H}_{2} \mathrm{~S}\right.$, organic sulfur, chlorinated hydrocarbons) compared to the Anoka site, the landfill clean-up cost increases by about $23 \%$ to approximately $\$ 1.24 / \mathrm{MMBTU}$.

Testing of a $32 \mathrm{~kW}$ carbonate fuel cell stack at ERC on clean simulated landfill gas for 500 hours verified predicted performance levels which are only slightly below performance levels on natural gas. This is due to the lower heating value of LFG. Based on this performance level, a nominal $3 \mathrm{MW}$ carbonate fuel cell system operating on LFG would achieve an efficiency of $50 \%$ LHV.

Single cell testing at ERC to assess the impact of higher tolerance levels for sulfur and chlorine contaminants in LFG were conducted at the $300 \mathrm{ppb}$ contaminant level. Based on two tests conducted, the presence of $300 \mathrm{ppb}$ chlorides did not result in severe decay rates compared to other standard cells tested. The $300 \mathrm{ppb}$ sulfur did result in noticeable contamination of internal reforming catalyst. The limited data of these two tests does not preclude a future increase in tolerance for chloride contaminants, however, additional long-term data is warranted to support this conclusion. Increasing the tolerance level for sulfur to $300 \mathrm{ppbv}$ is not considered desirable due to the impact on internal reforming catalyst.

The LFG clean-up system achieved a high degree of gas clean-up approaching the desired level of $100 \mathrm{ppb}$ total chlorides and $100 \mathrm{ppb}$ total sulfur. Additional effort is required to obtain gas analysis with lower detection limits to establish the levels desired, and to address the removal of sulfur dioxide.

A demonstration test is recommended to address the remaining technical issues of gas analysis detection limits and reduction of sulfur dioxide levels. Following demonstration of the cleanup system, a fuel cell LFG demonstration should be conducted. 
LANDFILL GAS CleANuP FOR CARBONATE

FUEL CELL POWER GENERATION 


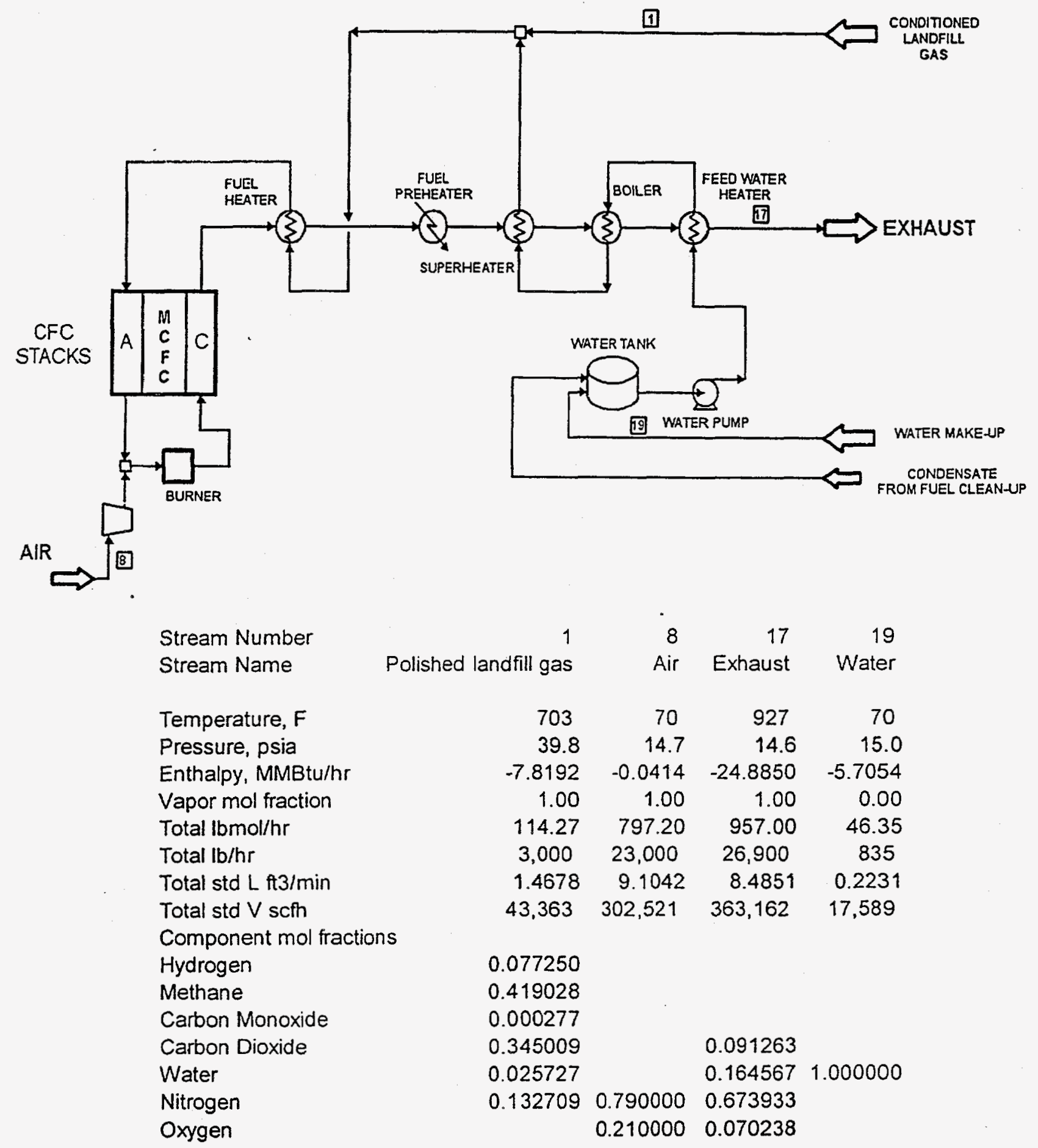

Figure A-1 2.77 MWe DIRECT CARBONATE FUEL CELL FLOW SHEET: Operation on LFG results in 50\% LHV efficiency. 